\title{
Making Government Pay: Markets, Politics, and the Allocation of Constitutional Costs
}

\author{
Daryl J. Levinson $\dagger$
}

\begin{abstract}
Instrumental analysis of private law damage remedies assumes rational economic actors in a market environment. A privately owned factory forced by the tort system to pay $\$ 1000$ in pollution costs suffered by a downstream neighbor will continue to pollute if, and only if, the private benefits of its pollution-producing activity exceed \$1000. At least within the law and economics paradigm, we can safely take for granted the rather strong assumptions upon which this analysis rests. No one doubts, for example, that a profit-maximizing firm will tend to ignore social costs that are not reflected in financial outflows, or that it will take account of costs that are reflected in financial outflows and, perhaps, change its behavior in response.

What happens, however, when government is substituted for the private firm in this analysis? This substitution takes place routinely in discussions of constitutional remedies such as just compensation for takings, damages for constitutional torts, and the liability or property rule represented by the constitutional prohibition against federal "commandeering" of state governments. Each of these remedial systems seeks to deter government, to some socially optimal extent, from violating constitutional rights by forcing government agencies to internalize the costs of their constitutionally problematic conduct.

But government does not internalize costs in the same way as a private firm. Government actors respond to political incentives, not financial ones-to votes, not dollars. We cannot assume that government will internalize social costs just because it is forced to make a budgetary outlay. While imposing financial outflows on government will ultimately create political costs (and benefits), the mechanism is complicated and depends on the model of government behavior used to translate between market costs and benefits and political costs and benefits. As this Article seeks to demonstrate by applying public choice models of government behavior, government cannot be expected to respond to forced financial outflows like a private firm. If the goal of making government pay compensation is to achieve optimal deterrence with respect to constitutionally problematic conduct, the results are likely to be disappointing and perhaps even perverse.

Having reached this conclusion, this Article proceeds to explore potential justifications for constitutional compensation remedies other than optimal deterrence of government misconduct. Efficiency justifications based on the incentives and welfare of private actors seem misguided and, in fact, often suggest efficiency gains from withholding, rather than paying, compensation. Moving from efficiency to "fairness," the conventional philosophical justifications for compensation, offered in terms of morality or justice, are at best contestable and incomplete. This Article concludes by exploring how we might reinvent constitutional remedies in light of the insight that government responds to political, not market, incentives.
\end{abstract}

Instrumental analysis of private law damage remedies assumes rational economic actors in a market environment. A privately owned factory forced by the tort system to internalize $\$ 1000$ in pollution costs suffered by a downstream neighbor will continue to pollute if, and only if, the private benefits of the pollution-producing activity exceed $\$ 1000$. Once the firm has internalized the full social costs and full social benefits of its activities, its self-interested, profit-maximizing deci-

$\dagger$ Associate Professor, University of Virginia School of Law. Thanks to Clay Gillette, Jack Goldsmith, Rick Hills, John Jeffries, Mike Klarman, Kevin Kordana, Liz Magill, Richard Merrill, Tom Merrill, Jim Ryan, and Bill Stuntz for useful comments on drafts, and to David Osswald for research assistance. 
sions about whether or how much to pollute will be both privately and socially optimal. Within the law and economics paradigm, this simple analysis is so conventional and noncontroversial that we can safely take for granted the rather strong assumptions upon which the analysis rests. No one doubts, for example, that a profit-maximizing firm will tend to ignore social costs that are not reflected in financial outflows, or that it will take account of costs that are reflected in financial flows and perhaps change its behavior in response.

These assumptions become problematic, however, when government is substituted for the private firm in this analysis. This substitution takes place routinely in discussions of constitutional remedies. Several important public law remedial systems seek to deter government, to some socially optimal extent, from violating constitutional rights by forcing government agencies to internalize the monetary costs of their constitutionally problematic conduct. ${ }^{1}$ Government entities and officials are liable for monetary damages to compensate the victims of constitutional violations. ${ }^{2}$ The eminent domain clause of the Constitution prohibits government from taking private property for public use without just compensation - in effect mandating a "remedy" of compensation for interference with certain constitutionally protected property rights. ${ }^{3}$ Stretching the analogy a bit further, recent federalism decisions of the Supreme Court in effect force the federal government to pay state and local governments for their assistance in implementing federal regulatory programs. ${ }^{4}$ We might refer generally

1 See, for example, Richard H. Fallon, Jr. and Daniel J. Meltzer, New Law, NonRetroactivity, and Constitutional Remedies, 104 Harv L Rev 1731, 1788-89 (1991) (stating conventional view that damages deter government misconduct and emphasizing deterrence as a central purpose of constitutional remedies); Daniel J. Meltzer, Deterring Constitutional Violations by Law Enforcement Officials: Plaintiffs and Defendants as Private Attorneys General, 88 Colum L Rev 247, 283 (1988) (acknowledging a common understanding that damages deter government misconduct).

242 USC Section 1983 (1994) authorizes an action for damages (or other relief) against any "person" who, acting "under color of" state law, denies any federal right. Bivens v Six Unknown Named Agents of Federal Bureau of Narcotics, 403 US 388 (1971), creates an analogous cause of action against federal officials.

3 US Const Amend V. No doubt this characterization will rub some readers the wrong way. It is more conventional to think of the takings "right" as being violated only when government takes property and fails to pay just compensation. On this understanding, the "remedy" for a takings violation ordinarily would be an injunction ordering government to pay just compensation. Readers who prefer the conventional understanding can rest assured that nothing of substance in this Article depends on which of the two labeling systems is employed. For an argument that we ought not to worry so much about sorting out the right from the remedy in takings and other contexts, see Daryl J. Levinson, Rights Essentialism and Remedial Equilibration, 99 Colum L Rev 857 (1999).

4 See Printz v United States, 521 US 898 (1997); New York v United States, 505 US 144 (1992). The Supreme Court held in these cases that the national government cannot "commandeer" state and local legislatures or executive officials to implement federal regulation of private activity. After Printz and New York, the federal government must pay the states money in order 
to mechanisms that force government to pay money in order to protect constitutional entitlements or deter constitutional violations as "constitutional cost" remedies. These remedies are meant to mirror their private law counterparts, using cost-internalization to force government to take full account of social costs in its decisionmaking processes.

In light of the similarities between the goals (deterrence) and mechanisms (cost-internalization) of private law damages and constitutional cost remedies, perhaps it should come as no surprise that courts and commentators have routinely applied conventional assumptions about the behavior of firms in market environments to government behavior. Discussions of constitutional cost remedies usually start from the assumption that the incentive effects of costinternalization will be the same for government as for private firms and that cost-benefit analysis by government decisionmakers will result in socially optimal choices about activities that threaten constitutional rights. Courts and commentators usually take for granted that government will respond to cost-internalization more or less like a corporation, so that requiring government to compensate the victims of takings or constitutional torts ensures that government will take full account of the costs of its actions.

If government does not respond to costs and benefits in the same way as a private firm, however, then none of these predictions about the instrumental effects of constitutional cost remedies on government behavior is likely to be accurate. In fact, for reasons that are elaborated below, there is every reason to expect government to behave quite differently from private firms. Because government actors respond to political, not market, incentives, we should not assume that government will internalize social costs just because it is forced to make a budgetary outlay. The only way to predict the effects of constitutional cost remedies is to convert the financial costs they impose into political costs. This may be possible, but only by constructing models of government decisionmaking that are capable of exchanging economic costs and benefits into political currency. As this Article goes on to demonstrate, any such model will be highly contextual, complex, and controversial.

In short, this Article seeks to expose, and then move beyond, the present confusion about how government responds to constitutional costs (and benefits). It also examines the justification for constitu-

to buy their consensual participation in federal regulatory programs.

5 Of course, government is subject to monetary damages in many non-constitutional settings as well. While this Article focuses (somewhat arbitrarily) on constitutional cost remedies, much of the analysis of government behavior in response to monetary outflows is perfectly generalizable to non-constitutional government torts, breaches of contract, and statutory violations. 
tional cost remedies in a world where government cannot be expected to respond to forced financial outflows in any socially desirable, or even predictable, way. Part I reveals the peculiar assumptions about government behavior in the existing literature and questions the facile analogy between government and private firms. By foregrounding the differences between the behavior of market actors and political actors, this Part introduces the question of how government does, in fact, respond to the internalization of constitutional costs. Part II presents some potentially fruitful ways of answering that question by exploring the effects of constitutional cost remedies as predicted by various models of government behavior. In doing so, however, it illustrates the complexity and indeterminacy of such predictions. Different models yield different outcomes; numerous variables are relevant, many of which are difficult to measure or quantify; and results that may seem plausible in specific situations are extremely difficult to generalize. The analysis in Part II ultimately suggests that we have little basis for expecting government to respond to constitutional cost remedies in any socially beneficial way. Part III, therefore, brackets the instrumental effects on government behavior as a justification for constitutional cost remedies, and questions whether there are other convincing justifications, instrumental or noninstrumental, for making government pay. The tentative answer is that none of the prevailing justifications for mandatory compensation of takings or constitutional torts is adequate, or even very promising. Parts II and III add up to an argument that the judicial requirement of compensation in these settings is far more difficult to justify, in terms of efficiency or fairness, than most people assume. The Article thus suggests that compensation remedies, which make perfect sense in the realm of markets, do not translate very well into the realm of politics.

\section{FROM MARKETS TO POLITICS}

A. Divergent Models of Government Incentives in Takings and Constitutional Torts

The most straightforward attribution of market behavior to government actors comes in economic analyses of takings and just compensation, where commentators explicitly model government as a rational cost-benefit calculator. Judge Posner, for example, argues that the single best justification for compensating government takings is the effect of cost-internalization on government decisionmaking. Starting from the premise that government "operate[s] with an incentive structure similar to that of a similarly situated private enterprise," Posner uses a simple illustration to carry through the private law analogy: 
Suppose the government has a choice between putting up a tall but narrow building on a small lot and a short but wide building on a large one. The market value of the small lot is $\$ 1$ million and of the large lot $\$ 3$ million. The tall narrow building would cost $\$ 10$ million to build and the short wide one $\$ 9$ million. The cheaper alternative from the standpoint of society as a whole is to build the tall building on the small lot (total cost: $\$ 11$ million) rather than the short building on the large lot ( $\$ 12$ million). But if the land is free to the government, it will build the short building on the large lot, for then the net cost to it will be $\$ 1$ million less."

Forcing the government to pay compensation, according to Posner, thus "prevents the government from overusing the taking power." This "efficiency" rationale for compensating takings has been relied upon at least since Frank Michelman's foundational article on takings," and it remains widely accepted by economically minded commentators as the most important justification for just compensation. As Michael Heller and James Krier summarize the standard account, "If the government were free to take resources without paying for them, it would not feel incentives, created by the price system, to use those resources efficiently."

This efficiency argument rests on the premise that, just as a private actor will not weigh externalized public costs as private costs, government will not take full account of the costs of takings unless it is forced to pay money from the treasury. Bracketing, for now, the

6 Richard A. Posner, Economic Analysis of Law 64 (Aspen 5th ed 1998).

7 Richard A. Posner, Economic Analysis of Law 58 (Little, Brown 4th ed 1992). Posner does go on to recognize that "government procurement decisions cannot be assumed to be made on the same profit-maximizing basis as private procurement decisions," but then partially retracts the retraction, stating that "it would be reckless to assume that the government is immune to budgetary considerations and could therefore be relied on always to buy the socially least costly inputs, regardless of their price." Posner, Economic Analysis of Law at 64 (5th ed) (cited in note 6). For those keeping score, further ambivalence about the private firm model of government arises later in Posner's discussion of takings. See id at 66-67.

8 See Frank I. Michelman, Property, Utility, and Fairness: Comments on the Ethical Foundations of "Just Compensation" Law, 80 Harv L Rev 1165, 1218 (1967) (explaining that forcing government to pay compensation tests the efficiency of takings).

9 See, for example, Michael A. Heller and James E. Krier, Deterrence and Distribution in the Law of Takings, 112 Harv L Rev 997, 999 (1999); Thomas W. Merrill, Dolan v. City of Tigard: Constitutional Rights as Public Goods, 72 Denver U L Rev 859, 882-83 (1995); Thomas J. Miceli and Kathleen Segerson, Regulatory Takings: When Should Compensation Be Paid?, 23 J Legal Stud 749, 758-59 (1994); Richard A. Epstein, Bargaining with the State 182-83 (Princeton 1993); Michael H. Schill, Intergovernmental Takings and Just Compensation: A Question of Federalism, 137 U Pa L Rev 829, 859-60 (1989); Robert Cooter, Unity in Tort, Contract, and Property: The Model of Precaution, 73 Cal L Rev 1, 21-22 (1985); Lawrence Blume and Daniel L. Rubinfeld, Compensation for Takings: An Economic Analysis, 72 Cal L Rev 569, 571 (1984).

10 Heller and Krier, 112 Harv L Rev at 999 (cited in note 9). 
plausibility of this understanding of government behavior, notice the following asymmetry: government internalizes social costs if, and only if, they are translated into budgetary outflows, but at the same time, government internalizes social benefits even if they are not translated into budgetary inflows. If government does not fully internalize the costs of takings unless it must spend its revenues to pay compensation, then why should we expect government to fully internalize the benefits of takings when it does not receive them in the form of revenues? Governments, after all, do not usually seek restitution for the economic benefits derived by private actors from the programs and regulations that inflict takings costs. ${ }^{12}$ Yet the takings literature mysteriously assumes that government policymakers discount social costs that are not translated into budgetary expenditures, but do not similarly discount the social benefits derived from government programs. For purposes of internalizing costs, in other words, government behaves like a private actor in a market environment. For purposes of internalizing benefits, however, government exhibits a more altruistic, public-regarding welfare function, weighing externalized benefits as if they were enjoyed by government itself. One searches the takings literature in vain for some explanation of this puzzling asymmetry. ${ }^{13}$

Now compare conventional accounts of the cost-internalization function of constitutional tort damages. Courts and commentators routinely assume that such damages will create incentives for government to avoid constitutional violations much as ordinary tort damages create incentives for private parties to take precautions against accidents. ${ }^{14}$ Forcing government to pay the costs of constitutional viola-

11 This question has been posed by Louis Kaplow. See Louis Kaplow, An Economic Analysis of Legal Transitions, 99 Harv L Rev 509, 567-68 (1986).

12 Government sometimes does extract payments from the beneficiaries of its programs through special assessments and user fees, but probably not often enough for cash returns to be viewed as a substantial factor motivating government behavior on the benefits side. See Saul Levmore, Just Compensation and Just Politics, 22 Conn L Rev 285, 290-93 (1990). For a more thorough survey of the extent to which government benefits are recaptured through taxes or fees, and arguments for why they should be recaptured to a greater extent, see Donald G. Hagman and Dean J. Misczynski, eds, Windfalls for Wipeouts: Land Value Capture and Compensation (Am Society of Planning Officials 1978).

13 Michael Schill at least recognizes the asymmetry. He points to several empirical studies finding that government bureaucrats overestimate benefits and underestimate costs but offers no theory that would explain these results. See Schill, $137 \mathrm{U}$ Pa L Rev at $860 \mathrm{n} 116$ (cited in note 9).

14 See, for example, City of Riverside v Rivera, 477 US 561, 575 (1986) ("[T]he damages a plaintiff recovers contributes [sic] significantly to the deterrence of civil rights violations in the future."); Pembaur v City of Cincinnati, 475 US 469, 495 (1986) (Powell dissenting) ("The primary reason for imposing $\S 1983$ liability on local government units is deterrence, so that if there is any doubt about the constitutionality of their actions, officials will 'err on the side of protecting citizens' rights"), quoting Owen v City of Independence, 445 US 622, 652 (1980); Peter H. Schuck, Suing Government: Citizen Remedies for Official Wrongs 16-19 (Yale 1983); John C. Jeffries, Jr., In Praise of the Eleventh Amendment and Section 1983, 84 Va L Rev 47, 72 (1998); John C. Jeffries, Jr., Damages for Constitutional Violations: The Relation of Risk to Injury in Constitu- 
tions will, it is thought, create the "incentive for government to invest in the selection of personnel, legal training, effective supervision, internal reviews, and all the other strategies that can reduce the incidence of employee misconduct or error." ${ }^{\prime 1}$ As in the takings literature, the starting assumption is that government will not internalize the costs of constitutional violations unless it has to pay money for them and, conversely, that government will internalize these costs once it is forced to pay money to compensate for them.

In contrast to the takings literature, however, courts and commentators in the constitutional torts context seem to assume that government fails to fully internalize the benefits of its decisions. Most of the discussion of the incentive effects of constitutional tort damages takes place in debates over the proper scope of official immunities. The prevailing functional defense of qualified immunity is based on the argument that government officials who are exposed to money damages for the full costs of their constitutional violations will become overly cautious or quiescent, reducing their activity to suboptimal levels and shying away from socially beneficial risks. ${ }^{16}$ This depends on the assumption that government officials will not internalize the social benefits that their activity provides, as the following, typical, formulation of the argument makes clear. Consider the incentives of the "street-level" government officials (police officers, prison wardens and guards, school board members and teachers) who are the proximate perpetrators of most constitutional torts. From the perspective of a police officer, the argument goes, the personal rewards from vigorous performance of duties must be balanced against the personal threat of damages liability for constitutional violations. The risk of personal liability will tend to increase with the activity level of the police officer because inaction generally does not lead to suit, whereas each additional search or arrest creates some risk of running afoul of the Fourth Amendment. Yet the police officer does not capture the benefits of vigorous law enforcement, except insofar as the increase in public welfare (greater public safety and security) is translated into

tional Torts, 75 Va L Rev 1461,1462 (1989).

15 Jeffries, 84 Va L Rev at 72-73 (cited in note 14) (recounting the "instrumental case for strict liability" under Section 1983 that has "carried the day among scholars").

16 See, for example, Richardson v McKnight, 521 US 399, 407-08 (1997) (identifying qualified immunity as necessary to protect "government's ability to perform its traditional functions"); Scheuer $v$ Rhodes, 416 US 232, 240 (1974) (identifying as a rationale for official immunity "the danger that the threat of [ ] liability would deter [an officer's] willingness to execute his office with the decisiveness and the judgment required by the public good"); Schuck, Suing Government at 68-77 (cited in note 14); Jeffries, $84 \mathrm{Va} \mathrm{L} \mathrm{Rev} \mathrm{at} \mathrm{73-75} \mathrm{(cited} \mathrm{in} \mathrm{note} \mathrm{14);} \mathrm{Jerry} \mathrm{L.}$ Mashaw, Civil Liability of Government Officers: Property Rights and Official Accountability, $42 \mathrm{~L}$ \& Contemp Probs 8,26-29 (1978). 
performance bonuses, promotions, or other personal benefits. ${ }^{17}$ These skewed incentives will lead, the argument concludes, to a "strategy of personal risk minimization" or "unwarranted timidity" on the part of government officials. This argument has proved convincing not just to many commentators but also to the Supreme Court, which has provided executive officials some measure of protection against damage awards in the form of qualified immunity.

Although the asymmetric incentives argument typically focuses on street-level government officials, it must ultimately rest on the assumption that higher level, policymaking officials similarly fail to internalize social benefits. If the policymaking officials of the municipality that employs the police officer did fully internalize the social welfare gains from effective policing, then presumably they could use employment rewards and punishments (indemnification, bonuses, disciplinary measures, and the like) to bring their employees' interests in line with their own. ${ }^{21}$ There may be some reason to think that agency costs are higher in the public employment context than in the private sector, because constitutional and civil service rules constrain the discretion of policymakers to create incentives for lower level officials. Nevertheless, one would expect a municipality that internalized benefits like a private firm to be far more successful in tailoring the incentives of its police officers than the standard predictions of officer behavior under conditions of full damage awards suggest. ${ }^{23}$ Unless gov-

17 See Schuck, Suing Government at 68 (cited in note 14).

18 Id.

19 Richardson, $521 \mathrm{US}$ at 408.

20 With the exception of the President of the United States, see Nixon $v$ Fitzgerald, 457 US $731,749-57$ (1982) (holding that the President is absolutely immune from liability for official acts), all executive officers, from police officers and teachers to state governors, are entitled to qualified immunity from liability for constitutional violations. See Anderson $v$ Creighton, 483 US 635, 638 (1987); Malley v Briggs, 475 US 335, 340 (1986) (stating that for executive officers "qualified immunity represents the norm"). According to the Court, "[G]overnment officials ... are shielded from liability for civil damages insofar as their conduct does not violate clearly established statutory or constitutional rights of which a reasonable person would have known." Harlow v Fitzgerald, 457 US 800, 818 (1982).

21 But see Schuck, Suing Government at 82-88 (cited in note 14) (discussing practical difficulties of altering the incentives of street-level officials through indemnification).

22 See Jeffries, 84 Va L Rev at 75-76 (cited in note 14) (arguing that civil service regulations and procedural due process make government employees hard to fire); Schuck, Suing Government at 125-46 (cited in note 14) (surveying impediments to controlling low-level officials created by bureaucratic structures); Ronald A. Cass, Damage Suits Against Public Officers, $129 \mathrm{U}$ Pa L Rev 1110, 1164-68 (1981) (discussing the difficulty of controlling lower-level government officials). The fact that policymakers have only loose control over low-level officials in a government agency, however, does not necessarily lead to the conclusion that the low-level officials will perform their duties less aggressively than the policymakers would like. A principal armed with blunt incentives is just as likely to overcompensate for the potential chilling effect of individual damages liability, leading to overaggressive behavior by the agent. That is, the precision of incentives tells us nothing about the direction of their effects. See text accompanying note 121.

23 See Larry Kramer and Alan O. Sykes, Municipal Liability Under $\$ 1983:$ A Legal and 
ernment managers are drastically disabled from designing incentives for street-level officials that offset the deterrence effects of constitutional tort damages, the argument that officers subject to full damages will engage in personal risk minimization strategies must ultimately rest on the assumption that municipalities (or, more precisely, the policymaking officials who run them) themselves fail to capture the full benefits of aggressive police work and for that reason lack the motivation to realign the incentives of their agents. Indeed, this assumption is made explicit by other scholars who, in light of the nearuniversal government practice of defending and indemnifying officials against constitutional tort suits, focus more directly on the incentives of government-as-enterprise. These scholars argue explicitly that damage liability will result in inefficiently skewed incentives because government policymakers will weigh the on-budget costs of liability more heavily than the externalized benefits of efficacious public services. ${ }^{24}$

To make matters more confusing, some constitutional torts scholars advocate solving the skewed incentives problem by formally shifting liability from individual officers to government-as-enterprise. ${ }^{2 .}$ Direct enterprise liability would solve the problem, however, only if the government agency saddled with liability internalized the social benefits of its actions-a notion rejected by the argument in favor of qualified immunity. In any case, this new set of assumptions would just bring us back to the question raised by the takings literature: why do government agencies internalize social benefits without cash inflows but internalize social costs only if translated into cash outflows?

In sum, theorists of takings and constitutional torts seem deeply confused about the relationship between social costs and benefits, budgetary inflows and outflows, and the calculus of government decisionmaking. Courts and commentators in both areas seem to agree that government will not internalize social costs unless it has to pay compensation from the treasury, and also that government will, in fact, internalize the costs if such payments are made. The across-the-board

Economic Analysis, 1987 S Ct Rev 249,274-76.

24 See Jeffries, 84 Va L Rev at 76-77 (cited in note 14); William J. Stuntz, Warrants and Fourth Amendment Remedies, 77 Va L Rev 881,905 (1991).

25 See Mark R. Brown, The Demise of Constitutional Prospectivity: New Life for Owen?,79 Iowa L Rev 273, 305-11 (1994); Harold S. Lewis, Jr. and Theodore Y. Blumoff, Reshaping Section 1983's Asymmetry, $140 \mathrm{U}$ Pa L Rev 755, 826 (1992); Laura Oren, Immunity and Accountability in Civil Rights Litigation: Who Should Pay?, 50 U Pitt L Rev 935, 1000-07 (1989); Schuck, Suing Government at 82-121 (cited in note 14). The Supreme Court has allowed enterprise liability under Section 1983 for local governments, but only for constitutional violations committed pursuant to official "policy or custom." Monell $v$ Department of Social Services of the City of New York, 436 US 658, 694 (1978). States and state officials acting in their official capacities are immune from Section 1983 damages liability under the Eleventh Amendment. See Quern v Jordan, 440 US 332, 338-45 (1979). 
assumption with respect to costs, therefore, seems to be that government will behave like a private, profit-maximizing firm. Theories of takings and constitutional torts disagree, however, in their assumptions about the extent to which government internalizes the social benefits of its activities. Courts and commentators concerned with takings generally assume that government internalizes social benefits through some mechanism other than budgetary inflows. Evidently they believe that government is different from a private firm in this respect, but for enigmatic reasons. What is the mechanism by which government internalizes benefits, and why does this mechanism cease to work on the cost side? While some constitutional tort theorists share the view that government somehow internalizes social benefits, others, along with the Supreme Court, apparently believe that government does not fully internalize the social benefits of its activity. On this understanding, government behaves exactly like a private firm, internalizing costs and benefits that affect its budget and externalizing all off-budget costs and benefits.

\section{B. Government as Firm?}

Recall that the private law model is premised on the understanding that firms in a market environment will rationally seek to maximize wealth by weighing the economic costs and benefits of their activity. ${ }^{26}$ Let us examine the basis for this understanding more closely. From an economic perspective, only individual actors, not institutions, can be expected to behave as rational maximizers of their self-interest. When economists abandon methodological individualism by ascribing rationality to firms rather than treating them as collections of rational individuals, they rely on empirical claims about firm behavior that are plausible only in the special environment of the economic market. ${ }^{27}$ Private firms, such as corporations and partnerships, are owned by individual investors who, as the residual claimants of the firm, have selfinterested incentives to maximize the firm's profits. ${ }^{28}$ Investors have strong incentives to monitor the behavior of their agents, the firm managers, to ensure that they maximize firm profits rather than pursuing their own self-interested agendas. ${ }^{29}$ (Note that the managers will seek to maximize their own welfare, and will have no interest in the profitability of the firm unless their incentives are brought into line with the incentives of the investors through the exercise of investor

\footnotetext{
26 See text accompanying notes $1-5$.

27 See Edward Rubin, Rational States?,83 Va L Rev 1433, 1441 (1997).

28 Some firms, such as non-profits, are not investor-owned. The discussion that follows sets these aside and uses "firm" to mean "investor-owned" firm.

29 See Rubin, 83 Va L Rev at 1438-39 (cited in note 27).
} 
control.) Furthermore, investors will exit firms that fail to maximize profits, selling their shares to investors willing to install and monitor new management who will do a better job of maximizing value. And firms in competitive markets that consistently fail to maximize profit will eventually face bankruptcy. These complementary mechanisms of investor control and selection justify-within reasonable limitsmodeling firms operating in economic markets as profit-maximizers. ${ }^{30}$

Government works somewhat differently. Pursuing the private firm analogy, citizens of a political jurisdiction might be considered the residual claimants of that jurisdiction, and government officials their agents. Citizens, however, are not uniquely interested in maximizing the profits, or total wealth, of the jurisdiction. Unlike owners of private firm equity, who generally receive a pro rata share of firm profits based on their ownership interest, citizens have no similar expectation of equal economic treatment. ${ }^{31}$ Pro rata distribution tends to create homogeneous incentives among investors to maximize firm value. Where redistribution is permitted, however, self-interested citizens will not support policies that maximize collective wealth unless these policies also maximize their individual wealth. Consequently, even strictly wealth-maximizing citizens will have heterogeneous and often conflicting preferences.

But of course citizens often have interests in the political sphere other than individual wealth-maximization. Political preferences may differ systematically from market preferences, reflecting not just immediate self-interest but altruism and individual and collective aspirations. ${ }^{32}$ These moral and ideological preferences are obviously far from homogeneous, but even if they were, giving effect to them would mean sacrificing some measure of wealth-maximization in order to realize other social goals. Unlike investors in private firms, then, the principals of governments do not share a singular interest in maximizing firm value. Even if government officials were perfectly faithful and efficacious agents of their constituents, therefore, government would behave quite differently from a profit-maximizing firm.

But we should not expect government officials to be such perfect agents. To the contrary, because control and selection mechanisms are much weaker in the political sphere than in economic markets, we should expect the actions of public agents as compared to private agents to diverge from their principals' interests to a much greater ex-

30 See id.

31 See Daniel R. Fischel and Alan O. Sykes, Governmental Liability for Breach of Contract 17-18 (unpublished draft on file with U Chi L Rev).

32 See Cass R. Sunstein, Free Markets and Social Justice 21-24 (Oxford 1997) (describing and explaining citizens' collective decisionmaking). 
tent. ${ }^{33}$ The control mechanism is undermined in politics by higher monitoring costs resulting from the diverse and difficult-to-quantify goals that government legitimately pursues. There is no single benchmark equivalent to firm value for evaluating the performance of government. ${ }^{34}$ Effective control is further hindered by the weak incentives for individual voters to invest in monitoring. ${ }^{35}$ In contrast to corporate law, which correlates voting power with economic stake and thereby creates incentives for the most interested shareholders to invest in monitoring, democratic equality norms-such as one person, one vote-ensure that no individual voter has more than a trivial selfinterested incentive to seek information about the behavior of government officials.

The selection mechanism is also less effective in the political sphere. While it is true that bad politicians, like bad managers, can be removed from office, there is no equivalent to the corporate takeover market for wholesale displacement of a government that fails to maximize the interest of its principals. ${ }^{37}$ Nor are there close equivalents to market competition or the threat of bankruptcy for selectively eliminating inefficient government entities. ${ }^{38}$ In sum, government officials enjoy substantial freedom to maximize their own self-interest in various ways at the expense of the interests of their principals. And, as we have seen, insofar as they do further the interests of their principals, those interests may not be congruent with maximizing social wealth or welfare. There is simply no basis, then, for assuming that government, as a collective entity, will rationally pursue any particular goal, let alone rationally maximize wealth or any other single variable.

In short, we cannot assume that government will behave like a private, profit-maximizing firm. Yet the prevailing approaches to takings and constitutional torts make just this assumption. By now it

33 See Rubin, 83 Va L Rev at 1441-42 (cited in note 27); Fischel and Sykes, Governmental Liability at 15-18 (cited in note 31 ).

34 See Fischel and Sykes, Governmental Liability at 16 (cited in note 31).

35 See Clayton P. Gillette, The Exercise of Trumps by Decentralized Governments, 83 Va L Rev 1347, 1382-83 (1997).

36 See Fischel and Sykes, Governmental Liability at 16-17 (cited in note 31).

37 See id at 18; Rubin, 83 Va L Rev at 1442 (cited in note 27).

38 See Fischel and Sykes, Governmental Liability at 18-19 (cited in note 31). The Tiebout jurisdictional competition literature offers an analogy to market selection and bankruptcy, but one that is quite limited. See Charles M. Tiebout, A Pure Theory of Local Expenditures, $64 \mathrm{~J}$ Polit Econ 416 (1956). For useful discussions of the conditions under which jurisdictional competition can be expected to exert some pressure toward the provision of an efficient level of public goods, see William W. Bratton and Joseph A. McCahery, The New Economics of Jurisdictional Competition: Devolutionary Federalism in a Second-Best World, 86 Georgetown L J 201 (1997); Richard L. Revesz, Rehabilitating Interstate Competition: Rethinking the "Race-to-the-Bottom" Rationale for Federal Environmental Regulation, 67 NYU L Rev 1210 (1992); George R. Zodrow, ed, Local Provision of Public Services: The Tiebout Model after Twenty-Five Years (Academic 1983); Wallace E. Oates, ed, The Political Economy of Fiscal Federalism (Lexington 1977). 
should be clear that this is a fundamental mistake. Forcing private firms to compensate for harms causes the firm to internalize social costs and weigh them in its decisionmaking calculus. This is true, however, only because private firms in market environments behave more or less like individual wealth-maximizers who attach disutility to financial outflows. Government does not behave like a wealthmaximizer, and therefore does not attach any intrinsic disutility to financial outflows-just as it attaches no intrinsic utility to financial inflows. Rather, government internalizes only political incentives. Political incentives are causally connected to social costs and benefits, but they are not the same thing, and the causal relationship between the two is, as we shall see, quite complicated. ${ }^{39}$ What is conspicuously missing from judicial and academic understandings of the effects of constitutional costs on government behavior is a model of government decisionmaking that explains how the social costs and benefits of government activity are systematically translated into private, political costs and benefits for government decisionmakers, and what role, if any, mandating financial outflows plays in this process. That is, predicting the effects of constitutional cost remedies on government behavior will require some understanding of the exchange mechanisms through which economic costs and benefits are converted into political currency.

\section{Two Understandings of Why Commandeering Is Bad}

The need for explicit attention to the relationship between fiscal costs and political incentives is nicely illustrated by recent controversies surrounding unfunded mandates and the constitutional prohibition against federal commandeering of state legislatures and executive officials. In New York v United States, the Supreme Court struck down a federal regulatory provision requiring states that were unable to provide for the disposal of their radioactive waste by a certain date to take title to the waste. This, explained the Court, amounted to unconstitutional "commandeering" of state governments by "directly compelling them to enact and enforce a federal regulatory program."." In Printz v United States, ${ }^{42}$ the Court extended the anticommandeering rule from state legislatures to state and local government executive officials by striking down the Brady Act's interim conscription of local

39 See Part II.

40505 US 144 (1992).

41 Id at 161, quoting Hodel v Virginia Surface Mining \& Reclamation Association, Inc, 452 US 264, 288 (1981).

42521 US 898 (1997). 
law enforcement officers to conduct background checks on prospective handgun purchasers.

Perhaps significantly, the federal programs invalidated in $\mathrm{New}$ York and Printz were in the form of unfunded mandates, forcing state and local governments to implement federal policies and to pay the costs. If these decisions are understood as allowing the federal government to impose funded mandates, requiring state and local governments to carry out federal policies but providing federal funds to cover the costs, then they create a simple intergovernmental takings rule. State governments are in effect granted an anticommandeering entitlement protected by a liability rule, leaving the federal government eminent domain power to impose mandates and then pay judicially determined costs as just compensation. ${ }^{43}$

Some commentators criticize unfunded mandates-and would presumably defend the anticommandeering principle to this extenton the familiar ground that unfunded regulations are likely to be inefficient and a threat to federalism values because they allow Congress to externalize the costs of regulating onto the states and thereby skew the federal cost-benefit calculus in favor of too much regulation. ${ }^{44}$ This is nothing more than the efficiency defense of just compensation applied to intergovernmental takings, and it rests on the same assumptions that Congress will somehow automatically internalize regulatory benefits but will internalize regulatory costs if, and only if, they are translated into budgetary outflows. Consider, for example, the sophisticated version of this argument recently developed by Roderick Hills. ${ }^{45}$ Hills attempts to defend New York and Printz against critics who argue that the anticommandeering rule will prevent efficient intergovernmental arrangements. The anticommandeering rule grants states a property right against federal commandeering and forces the federal government to purchase the services of state officials in market transactions. Hills argues that

43 See Roderick M. Hills, Jr., The Political Economy of Cooperative Federalism: Why State Autonomy Makes Sense and "Dual Sovereignty" Doesn't, 96 Mich L Rev 813, 934-38 (1998). On this understanding, only unfunded mandates are categorically prohibited. The Court may have a different understanding, however. The majority opinion in Printz suggests that even federally funded mandates may qualify as unconstitutional commandeering. See Printz, 521 US at 914, 930. If this is true, then the anticommandeering entitlement is protected not by a liability rule but a property rule, which in effect forces the federal government to buy states' consent to implement federal policies at a mutually agreed upon price. See Hills, $96 \mathrm{Mich} L \mathrm{Rev}$ at 822 . Nevertheless, to bring this version of the anticommandeering principle in line with the academic and political commentary on unfunded mandates, we might think of it as roughly equivalent to a ban on unfunded mandates enforced by a constitutional cost remedy that allows states unilaterally to determine their own costs.

44 See Robert W. Adler, Unfunded Mandates and Fiscal Federalism: A Critique, 50 Vand L Rev 1137, 1246,1246 n 499 (1997) (addressing this argument and citing sources).

45 See Hills, 96 Mich L Rev at 822-31 (cited in note 43). 
granting states this property right will not impede any cost-justified intergovernmental bargains because the federal government will be willing to pay for the use of state regulatory machinery when, and only when, state implementation would cost less than federal implementation. ${ }^{46}$ That is, the anticommandeering entitlement will be transferred to the level of government that values it the most. According to Hills, therefore, the anticommandeering rule tends to promote efficiency in intergovernmental arrangements by creating a financial disincentive for the federal government to commandeer in situations where the cost to state governments would exceed the benefits to the federal government.

Once again, this analysis works only if the federal government internalizes economic costs like a private firm - that is, exclusively when they are converted into financial outflows-even while it internalizes the benefits of its regulatory programs automatically, independent of any financial inflows. The analysis also assumes, oddly, that state governments will internalize the social benefits of implementing federal regulation only insofar as these benefits are translated into financial inflows in the form of payments by the federal government.

As Hills recognizes, however, the cost-internalization aspect of these assumptions would not hold unless regulatory costs translate proportionately into political costs for government decisionmakers." Yet Hills gives us no reason to think that regulatory costs and political costs would exhibit any such correspondence. ${ }^{48}$ Until we understand more generally how the costs and benefits of commandeering that are visited upon citizens translate into political incentives for government officials, we will have no basis for predicting how the anticommandeering rule, or any other constitutional cost remedy, will influence how governments behave.

In contrast to the straightforward cost-internalization approach, an alternative argument against unfunded mandates and commandeering actually does explore the relationship between economic and political costs. According to the Court and some commentators, unfunded congressional commandeering undermines political accountability by allowing members of Congress to take political credit for the benefits of federal regulatory programs while shifting the political

46 See id at $872-75$.

47 See id at $886-91$.

48 Hills does not pursue this point because the argument he wants to make does not depend on it. He is content to prove that we have no basis for predicting that the anticommandeering rule will deter cost-justified intergovernmental bargains or that repealing the rule would improve the results of cooperative federalism. True enough. What Hills leaves out, though, is that we also have no basis for predicting that the anticommandeering rule will deter inefficient intergovernmental bargains, or indeed that it will have any particular effect on the behavior of the local, state, or federal governments. 
blame for the costs of these programs onto state and local governments. ${ }^{49}$ Federal officials who enjoy the political benefits of regulation without suffering the political costs will tend to over-regulate. If, on the other hand, the federal government must pay for the implementation of its programs using federal tax revenue, federal elected officials will be forced to bear the political costs, along with the political benefits, of regulation. Thus, the argument goes, prohibiting unfunded mandates and commandeering will create balanced political incentives for federal officials, resulting in efficient regulatory decisions.

Now, as other commentators have been quick to point out, this "political accountability" argument is theoretically simplistic and empirically dubious. ${ }^{\text {so }}$ The argument relies on the premise that voters will mistakenly blame state and local officials for the tax consequences of federal unfunded mandates while crediting federal officials for the benefits of the mandates. This is far from obvious. Surely interest groups, at least, will have the incentive and means to inform themselves of the true sources of benefits and burdens so that they can direct their influence toward the appropriate level of government. As for individual voters, even if they are unsophisticated and easily conned by federal officials into believing they are getting something for nothing from the federal government, state officials will have strong incentives to correct this misunderstanding by educating voters about the real source of their tax burdens. In addition, unsophisticated voters might be at least as likely to credit the state and local officials they observe implementing a popular regulatory program as the distant federal representatives who mandated it. Cagey state and local officials might even manipulate voters into blaming the federal government for locally unpopular programs while taking credit themselves for locally popular ones. Certainly the fact that the federal government is often willing to provide block grants to states for programs such as welfare-using federal tax revenues to finance state regulatory schemes-suggests that federal representatives are not persuaded by the political accountability argument or that state and local officials

49 See Printz, 521 US at 929-30; New York, 505 US at 168-69. See also D. Bruce La Pierre, Political Accountability in the National Political Process-The Alternative to Judicial Review of Federalism Issues, $80 \mathrm{Nw}$ U L Rev 577, 656-65 (1985); Deborah Jones Merritt, The Guarantee Clause and State Autonomy: Federalism for a Third Century, 88 Colum L Rev 1, 61-62 (1988); Edward A. Zelinsky, Unfunded Mandates, Hidden Taxation, and the Tenth Amendment: On Public Choice, Public Interest, and Public Services, 46 Vand L Rev 1355, 1375-76 (1993).

50 See Evan H. Caminker, State Sovereignty and Subordinacy: May Congress Commandeer State Officers to Implement Federal Law?, 95 Colum L Rev 1001, 1060-74 (1995); David A. Dana, The Case for Unfunded Environmental Mandates, 69 S Cal L Rev 1, 10-25 (1995); Hills, 96 Mich L Rev at 822-30 (cited in note 43); Julie A. Roin, Reconceptualizing Unfunded Mandates and Other Regulations, 93 Nw U L Rev 351,375-80 (1999). 
have sufficient influence in the federal political process to protect themselves from unfunded mandates without judicial intervention.

Whatever the substantive merits of the political accountability objection to unfunded commandeering, however, its form is an important advance over the conventional ways of thinking about constitutional cost remedies because it at least attempts to take the crucial step of converting economic costs and benefits into political costs and benefits. Rather than assuming that government responds directly to social costs and benefits or to financial inflows and outflows, the accountability argument starts from the understanding that elected officials make decisions based solely on political costs and benefits. The argument therefore attempts to translate the economic benefits of federal programs into the political approval of the beneficiaries, and the economic costs of paying for these programs into political costs by way of political opposition to tax increases. This is a theoretically sound beginning to the project of modeling the behavior of government in response to constitutional cost remedies. Unfortunately, the mechanism of economic-political exchange hypothesized by the anticommandeering argument is not sufficiently well developed to be convincing on its own terms, let alone generalized to other contexts.

\section{POLITICAL MODELS AND CONSTITUTIONAL COSTS}

Predicting the effect of constitutional cost remedies (or anything else) on government behavior requires a model of government decisionmaking. This Part attempts to illustrate how such predictions might be made in the contexts of takings and constitutional torts by mobilizing the models of government behavior most prominent in constitutional law. Part II.A addresses "public interest" models of government behavior and explains that, even if they are accurate, such models can tell us nothing about the particular influence of constitutional cost remedies. Part II.B begins the real work by applying a simple majority rule model. Subsequent sections add complexity by introducing interest group analysis (Part II.C) and theories of bureau-cracy (Part II.D). The point of this analysis is decidedly not to provide a comprehensive, predictive account of government behavior in any given context. Quite the contrary, this Part demonstrates the difficulty of making any confident predictions of how government will behave in response to constitutional cost remedies. In doing so, the analysis

51 Understood as a ban on both unfunded and funded mandates, the anticommandeering principle is sufficiently different from other constitutional cost remedies that it is set aside after the present discussion. The remainder of the Article concentrates on the paradigmatic constitutional cost remedies, takings and constitutional torts. Extending the analysis in Part II to commandeering, while easily possible, would require attention to the distinctive feature that government entities are on both sides of the payment transaction. 
should cast considerable doubt on the assumptions about the deterrent effects of constitutional cost remedies currently taken for granted by courts and commentators. This Part concludes that there is little reason to believe that constitutional cost remedies are useful tools for shaping government behavior.

\section{A. Pursuit of the Public Interest}

While the idea that government policies are likely to be "publicregarding" or promote the "public interest" has long been out of fashion in the economic and political science literatures, constitutional law remains deeply wedded to descriptive and normative visions of public-regarding government behavior. ${ }^{52}$ Public interest theories of government have taken a number of different forms. Some hypothesize an objective social welfare function, the "public good," that transcends any aggregation of exogenous preferences. For example, neorepublican theory envisions the development of collective understandings of the public good through political deliberation among citizens or representatives imbued with civic virtue. ${ }^{53}$ Other public interest theories derive from a quite different, pluralist perspective, which denies the existence of any coherent "public good" apart from private preferences, and instead depicts the political process as a tournament of interest groups or coalitions. Optimistic pluralists speculate that legislative outcomes over time will accurately aggregate the preferences of all groups in society and thus, in the long term, maximize social welfare.

Republican and optimistic pluralist theories of government behavior are of little relevance for purposes of examining the incentive effects of constitutional cost remedies, however. This is not to deny the

52 For instance, mainstream constitutional discourse draws a distinction between legislative actions that are motivated by crass politics and those that are motivated by principled pursuit of some public good. See, for example, Ronald Dworkin, Freedom's Law: The Moral Reading of the American Constitution 30-31 (Harvard 1996) (distinguishing between ordinary politics and principled deliberation about the public good); Cass R. Sunstein, Naked Preferences and the Constitution, 84 Colum L Rev 1689 (1984) (arguing that a number of the most important constitutional provisions can be understood as preventing the political branches from distributing benefits on the basis of raw political power rather than in pursuit of some public value or conception of the good). See also Bruce Ackerman, 2 We the People: Transformations 6 (Belknap 1998) (distinguishing "normal" from "constitutional" politics).

53 See, for example, Cass R. Sunstein, Interest Groups in American Public Law, 38 Stan L Rev 29,31-32 (1985). For a general discussion on civic republicanism and constitutional law, see Symposium: The Republican Civic Tradition, 97 Yale L J 1493 (1988).

54 See Charles E. Lindblom, The Intelligence of Democracy: Decision Making Through Mutual Adjustment (Free Press 1965); Robert A. Dahl, A Preface to Democratic Theory (Chicago 1956). See also Jerry L. Mashaw, Greed, Chaos, and Governance: Using Public Choice to Improve Public Law 16 (Yale 1997) ("[O]n some descriptions pluralism is so open and inclusive a process that it amounts almost to consensus governance."). 
plausibility of such accounts, ${ }^{5 s}$ but only to make the rather obvious point that insofar as we can be confident that government decisionmaking is ultimately public-regarding-or, for that matter, that government decisionmaking converges on any pre-defined outcome ${ }^{36}-$ the incentive effects of constitutional cost remedies will be superfluous. If elected officials are responsive to citizens with publicregarding preferences, or if these officials act on their own publicregarding preferences, then social costs and benefits will be incorporated into the public-regarding welfare function regardless of whether they are translated into budgetary outflows or inflows. If optimistic pluralism prevails and citizens' preferences are accurately aggregated in a well functioning political market, then it is also hard to see why constitutional cost remedies would make any difference. Burdens and benefits would be distributed according to politically expressed constituent demand, as measured by numbers and intensities of preference, and the advantages of individuals and groups with constitutionally secured claims to compensation for certain types of burdens would presumably be offset by disadvantages in other contexts where they did not possess constitutional trumps. In short, insofar as public interest models assert that government is motivated to shape and pursue some vision of the public good or to respect all political interests equitably, constitutional cost remedies will play no part in government decisionmaking.

\section{B. Majority Rule}

Simple majority rule, if not the single best "mark of a democratic form of government," is certainly the basic background principle of democratic decisionmaking in constitutional law. ${ }^{\text {ss }}$ Assume, therefore, a highly stylized form of majority rule under which fully informed citizens vote their self-interest, each citizen gets one vote, and govern-

55 For a critical overview of public interest theories of regulation and legislation, see Richard A. Posner, Theories of Economic Regulation, 5 Bell J Econ \& Mgmt Sci 335, 336-41 (1974); Daniel Shaviro, Beyond Public Choice and Public Interest: A Study of the Legislative Process as Illustrated by Tax Legislation in the 1980s, 139 U Pa L Rev 1,31-50 (1990).

56 This includes allocative efficiency. For example, if jurisdictional competition exerts pressure on local governments to provide an efficient level of public goods and to avoid redistribution, then uncompensated takings may generally be efficient. See note 38 .

57 Dennis C. Mueller, Public Choice II 63 (Cambridge 1989). See also Robert A. Dahl, Democracy and Its Critics 135 (Yale 1989) (discussing the merits of majority rule).

58 See, for example, John Hart Ely, Democracy and Distrust: $A$ Theory of Judicial Review 7 (Harvard 1980) ("Our constitutional development over the past century has therefore substantially strengthened the original commitment to control by a majority of the governed. Neither has there existed among theorists or among Americans generally any serious challenge to the general notion of majoritarian control."). 
ment accurately records and acts upon the preferences of a majority of citizens.

\section{Takings.}

Assume, as do the standard economic analyses of takings, that the purpose of requiring just compensation is to encourage government to make efficient regulatory decisions - that is, only to regulate where the social benefits of the regulation exceed the social costs. Now, consider a jurisdiction of ten citizens and a proposed regulation that would cost citizen $1 \$ 10,000$ and benefit each of citizens $2-10$ by $\$ 100$. (Imagine taking a large chunk of citizen 1's land to expand a highway used by all the citizens, or forbidding citizen 1 from developing his wetlands to protect an endangered species.) Whereas a publicregarding government would weigh the social costs of the regulation $(\$ 10,000)$ against the social benefits $(\$ 900)$ and refuse to regulate, a majority vote would approve the inefficient regulation by a margin of nine to one. Suppose that a constitutional just compensation requirement is now implemented. If the regulation passes, citizen 1 will have a claim against the government for just compensation of $\$ 10,000$. For the sake of simplicity, assume that the compensation payment will be made from tax revenues collected on a uniform per capita basis from all of the citizens and that the transaction costs of taxing and paying compensation are zero. Citizens 2-10 each calculate that if the regulation passes, they will gain $\$ 100$ in direct benefits but have to pay a $\$ 1000$ compensation tax, for a net loss of $\$ 900$. Citizen 1 calculates losing $\$ 10,000$ from the regulation, collecting $\$ 10,000$ in offsetting compensation, and having to pay $\$ 1000$ in taxes, for a net loss of $\$ 1000$. The vote is ten to zero against the regulation and efficiency prevails..$^{60}$ Thus far, the political analysis of the effect of compensation corroborates the unschooled economic intuition that government will respond like a private firm.

It is important to recognize, however, that the political analysis is sensitive to the magnitude of costs and benefits. Suppose that the regulation would benefit each of citizens $2-10$ by $\$ 1010$ and would

59 The constitutional just compensation requirement is relevant only to regulations that constitute "takings" under some positive or normative theory of the scope of the takings clause. The analysis that follows does not depend on the coverage of the takings clause, except that it assumes that ordinary taxation does not count as a taking. This assumption will be controversial only to those who believe that any form of government redistribution counts as a taking. The leading, and perhaps only, commentator who takes this position is Richard Epstein. See Richard A. Epstein, Takings: Private Property and the Power of Eminent Domain 295-303, 306-29 (Harvard 1985) (introducing the thesis that the takings clause applies to government transfer payments and progressive taxation).

60 A similar illustration is presented by Neil Komesar. See Neil K. Komesar, Imperfect Alternatives: Choosing Institutions in Law, Economics, and Public Policy 241-42 (Chicago 1994). 
cost citizen $1 \$ 10,000$. Social costs $(\$ 10,000)$ still outweigh social benefits (\$9090), but now the regulation will pass in a majority vote. Citizens $2-10$ each stand to gain $\$ 10$ (benefits of $\$ 1010$ minus $\$ 1000$ in taxes); citizen 1 stands to lose $\$ 1000$ (her share of the compensation tax); the vote is nine to one in favor and inefficiency prevails, even with just compensation in effect. This is by no means an outlier result. Although it is true that when the number of citizens in a jurisdiction gets large and the number of victims stays very small, the room for inefficient regulation disappears, ${ }^{61}$ the examples used so far misleadingly stack the deck against the passage of inefficient regulation by assuming supermajority coalitions. In fact, majority voting theory predicts that regulatory proposals will be tailored to attract the support of minimum winning coalitions because this will maximize the benefits to individual members of the majority. ${ }^{62}$ So, consider a more likely case: the proposed regulation will benefit each of citizens 1-6 (the members of the minimum winning coalition) by $\$ 2000$, while costing each of citizens 7-10 $\$ 4000$. Citizens $1-6$ will support the regulation because it leaves them better off by $\$ 400$ ( $\$ 2000$ in direct benefits minus onetenth of $\$ 16,000$, or $\$ 1600$, in compensation taxes), and the inefficient regulation will therefore pass. ${ }^{63}$ We should expect most proposed regulations with redistributive effects to resemble this example, for supermajority coalitions will always have the incentive to expel all members in excess of a bare majority. ${ }^{4}$ This is not to say that most

61 The possibility of inefficient regulation depends on the ratio of beneficiaries to costbearers. If costs are spread evenly among all citizens, and benefits are spread among all citizens except for a single condemnee, then this ratio will approach $1: 1$ as population increases, leaving no room for inefficient regulation. In a jurisdiction with 100,000 citizens, for example, compensated takings from one citizen will cost each member of the majority $1 / 100,000$ of the cost and benefit each member of the majority $1 / 99,999$ of uniformly dispersed total benefits.

62 See William H. Riker, The Theory of Political Coalitions (Yale 1962).

63 Incidentally, one could use this example to make an economic argument for reinvigorating the "public use" requirement for takings. As a matter of constitutional doctrine, the public use limitation has been long dead. See Hawaii Housing Authority v Midkiff, 467 US 229, 241 (1984) (stating that "where the exercise of the eminent domain power is rationally related to a conceivable public purpose, the Court has never held a compensated taking to be proscribed by the Public Use Clause"); Epstein, Takings at 161-62 (cited in note 59). Suppose the public use limitation were resurrected as a requirement that the beneficiary coalition for a taking constitute a supermajority of the population of the relevant jurisdiction. Then the requirement would tend to deter inefficient takings, which, as the example in note 61 illustrates, become less likely as the size of the majority coalition increases. For further speculation about the beneficial role of a public use requirement against the background of an interest group model of the political process, see note 90 .

64 Cycling will be an added source of inefficiency in any majority rule system engaged in redistributive takings. Each member of the losing coalition will have the incentive to bribe the members of the majority coalition to substitute her for one of their own number. This process of bribery and reshuffling could, in theory, go on indefinitely. See Mueller, Public Choice II at 63-65 (cited in note 57). Note that whether compensation is paid to the losers will affect the amount minority members will be prepared to offer for inclusion in the majority coalition. If compensation is paid, the condemnees stand to lose $\$ 1600$ and would pay up to that amount to be included 
regulations will be inefficient, of course, but only that a compensation requirement will not necessarily prevent those inefficient regulations that are proposed from being approved. And there is good reason to expect that sometimes inefficient regulations will be in the interest of the majority. For example, the majority would prefer the inefficient regulation just discussed to an efficient alternative that would benefit citizens $1-6$ by $\$ 500$ each (social gain of $\$ 3000$ ) and cost citizens $7-10$ $\$ 600$ each (social cost of $\$ 2400$ ).

The above analysis assumes broad-based, uniform taxation to pay for compensation. If instead compensation were financed from a tax on regulatory windfalls, only efficient regulations would win majority support. ${ }^{65}$ Such a scheme would be functionally equivalent to a unanimity rule, which effectively bars all but Pareto-superior regulation. ${ }^{6}$ Realistically, however, for the same reasons that majority coalitions will tend to pass regulations that benefit themselves at the expense of minorities, they will tend to impose taxes that minimize the costs to themselves. Uniform taxation is already an optimistic assumption; windfall taxation seems highly unlikely. The analysis further assumes that the compensation requirement covers the direct costs of regulation (or some subset of regulation) but not net losses resulting from taxation. This accurately reflects takings law as it currently stands or plausibly might be reformed. If net tax losses were counted as takings and triggered the just compensation requirement, however, it is true that only efficient regulation would pass. Intuitively, a takings system that demands compensation for any net loser from a given regulation (or package of regulations) will effectively prevent any regulation that does not create social benefits at least sufficient to cover its own costs. ${ }^{6}$ Inefficient takings are a concern only in political systems that allow for the possibility of redistribution.

\footnotetext{
in the majority coalition. Without compensation, the condemnees would stand to lose $\$ 4000$ and would offer correspondingly larger bribes. Once transaction costs are introduced, it is possible that the greater stakes of the non-compensation world would lead to more cycling and higher transaction costs than in the compensation world. The efficiency consequences would depend on weighing the deadweight losses from cycling against the savings in social costs from averting inefficient regulation minus the lost social benefits from averted efficient regulation.

65 For arguments in favor of using windfall tax revenues to compensate takings victims, see Hagman and Misczynski, eds, Windfalls for Wipeouts 31-71 (cited in note 12); Saul Levmore, Takings, Torts, and Special Interests, 77 Va L Rev 1333, 1355-56 (1991). Using a formal majoritarian model that relies on the (unrealistic) assumption that government raises the money to pay compensation by taxing only non-victims of takings, Fischel and Shapiro derive the result that government will take too much if it is not required to pay just compensation. See William A. Fischel and Perry Shapiro, A Constitutional Choice Model of Compensation for Takings, 9 Intl Rev L \& Econ 115, 118-24 (1989).

66 See James M. Buchanan and Gordon Tullock, The Calculus of Consent: Logical Foundations of Constitutional Democracy 85-96 (Michigan 1962).

67 This is one of the central points of Epstein, Takings at 199-204 (cited in note 59).
} 
To summarize, if government is directly responsive to majority rule, then forcing payment of compensation for takings out of broadbased tax revenues will deter a category of the most severely inefficient takings, but by no means all inefficient takings. Essentially, the just compensation requirement spreads the costs of regulation while allowing the benefits to remain localized within the majority coalition. Compared to a non-compensation system that allowed both the benefits and costs to remain localized (within the majority and minority coalitions respectively), just compensation does create some pressure toward efficiency in government takings decisions by deterring a category of inefficient regulations that would otherwise pass. This falls far short, however, of the conventional, stronger claim that just compensation will systematically prevent inefficient takings by forcing government to internalize the costs and weigh them against the benefits. ${ }^{6 .}$

\section{Constitutional torts.}

Extending a majority rule analysis of optimal deterrence to constitutional torts requires some explanation, for we do not usually think of violations of constitutional rights in terms of cost-benefit analysis and efficiency. Quite the opposite, constitutional rights are most commonly conceived as deontological side-constraints that trump even utility-maximizing government action. ${ }^{69}$ Alternatively, constitutional rights might be understood as serving rule-utilitarian purposes. If the disutility to victims of constitutional violations often exceeds the social benefits derived from the rights-violating activity, or if rights violations create long-term costs that outweigh short-term social benefits, then constitutional rights can be justified as tending to maximize global utility, even though this requires local utility-decreasing steps. Both the deontological and rule-utilitarian descriptions imply that the optimal level of constitutional violations is zero; that is, society would be better off, by whatever measure, if constitutional rights were never violated.

On this understanding of constitutional rights, however, awarding compensation to the victims of constitutional violations would not seem to have any deterrent effect on government. If every constitu-

68 To be clear, this discussion makes no claims about whether takings generally will or will not be efficient, only about the relationship between compensation and efficiency. No doubt there are many reasons why takings might or might not be efficient that have nothing to do with the payment of just compensation. Perhaps majoritarian governments will only engage in efficient takings because this will maximize the political benefits and minimize the political costs. Or perhaps jurisdictional competition will exert pressure on governments only to take efficiently and not to engage in redistributive takings. These possibilities are irrelevant to the analysis presented here.

69 See Ronald Dworkin, Taking Rights Seriously 184-205 (Harvard 1977). 
tional violation is "efficient," in the sense that the benefits to society outweigh the immediate costs to the victim, then spreading these costs through compensation will not hinder majoritarian support for violations. A police strategy of random searches of young men hanging out in high crime areas, for example, would fall within this category if it prevented many serious crimes while inflicting relatively minor costs, tangible or dignitary, upon the victims of these "unreasonable" (by Fourth Amendment standards) searches. Even if every victim were entitled to compensation, the majority of citizens would be happy to pay this price for the (by hypothesis) greater benefits of decreased crime. There is an important sense, of course, in which such violations are not "efficient," in light of the longer-term costs of breaking down ruleutilitarian norms or the moral costs of ignoring deontological prohibitions. But these costs are not reflected in the amount of compensation that is awarded to the immediate victim-indeed, it is hard to imagine how they could be-and therefore will not be passed on to citizens in the form of taxation. Perhaps citizens will independently take account of the long-term costs or wrongfulness of violating constitutional rights and vote against government decisionmakers who choose to do so, but if so this will not be a consequence of compensation for constitutional torts.

In practice, the situation is somewhat more complicated. Some types of constitutional violations resemble intentional torts or crimes in that they can be avoided with minimal effort or precaution-taking by government. The optimal level of violations of these rights may be close to zero. Given the constitutional prohibition against race discrimination, for example, there is no reason why a legislature should ever pass a racially discriminatory statute. This is not say that foregoing race discrimination has no opportunity costs. Certainly there are circumstances where race could be used as a relatively accurate, lowcost proxy for certain characteristics (voting for Democratic candidates, for instance). Race discrimination would yield some social benefits in those circumstances, but it is nevertheless constitutionally forbidden-because the social benefits of engaging in race discrimination are either trumped by the deontological right not to be classified on the basis of race or outweighed by the probabilisitic or long-term costs of race discrimination. ${ }^{70}$ The avoidance of race discrimination is costless only in the sense that government can comply with the constitutional prohibition at no additional cost, beyond the foregone benefits of engaging in the prohibited activity. The legislature need take no

70 In some circumstances the opportunity costs might be so high that the right can be permissibly infringed or suspended. For example, equal protection might permit temporary racial segregation in a prison in order to avoid a dangerous race riot. See City of Richmond $v$ J.A. Croson Co, 488 US 469, 521 (1989) (Scalia concurring) (suggesting this possibility). 
special precautions to avoid passing a statute that purposely discriminates based on race; to the contrary, it would have to invest time and effort to pass such a statute." In other words, while all (or virtually all $^{\text {T2 }}$ ) constitutional rights generate opportunity costs, not all constitutional rights generate compliance costs.

For categories of constitutional violations that do generate substantial compliance costs, we seem to accept, in practice if not in theory, that the optimal level of constitutional violations is greater than zero. Violations in this category resemble negligence torts more than intentional torts or crimes, in the sense that $B$ in the government's Hand formula, representing the compliance costs of avoiding constitutional violations, is positive and may even exceed $P L$.

Take Fourth Amendment search, arrest, and excessive force claims. In these areas, socially valuable activity runs up against uncertain standards of constitutional liability. The police will inevitably violate Fourth Amendment rights in the course of competent law enforcement work. In some cases, no remedy will be granted for violations (because of qualified immunity for police officers). In others, a municipality will pay damages but regard them as a routine cost of doing business because the benefits of aggressive policing are perceived to be worth the constitutional costs. ${ }^{3}$ The same is probably true of most other rights frequently litigated in constitutional tort suits, including procedural due process claims in a variety of settings, Eighth Amendment and free exercise claims by prisoners, and free speech claims in the context of government employment. ${ }^{74}$ Some sort of utili-

71 This situation might be reversed if equal protection could be violated by laws that had a disparate impact on racial minorities (or on any racially defined group) even without a racially discriminatory purpose. But see Washington v Davis, 426 US 229 (1976) (holding that disparate impact alone, without a showing of discriminatory purpose, is not sufficient to prove a violation of equal protection).

72 Some constitutional rights may generate zero opportunity costs because they forbid only conduct that has no legitimate social benefits, on some plausible theory permitting exclusion or discounting of certain kinds of benefits. For example, discrimination resulting from animus toward racial minorities or the desire to perpetuate white superiority may generate no social benefits that we would be willing to weigh in a utilitarian balance. Not counting these benefits might be equivalent to discounting the benefits experienced by rapists when deciding that rape imposes sufficient net costs to justify criminalization. So, although all constitutional violations probably increase the utility of at least one person, we might be willing to say that violation of some special types of constitutional rights generates no social benefits of the kind we are willing to count and, therefore, that there are no opportunity costs to enforcing these rights. Whether (and if so, why) some types of costs and benefits ought to be negated is a complicated philosophical question that can be safely bracketed for present purposes, however.

73 In other words, damage awards are structured as "prices" rather than "sanctions." See Robert Cooter, Prices and Sanctions, 84 Colum L Rev 1523 (1984).

74 For empirical data on the frequency of various types of constitutional tort litigation, see Theodore Eisenberg and Stewart Schwab, The Reality of Constitutional Tort Litigation, 72 Cornell L Rev 641 (1987); Stewart J. Schwab and Theodore Eisenberg, Explaining Constitutional Tort Litigation: The Influence of the Attorney Fees Statute and the Government as Defendant, 73 Cor- 
tarian calculation is clearly taking place for tort-like constitutional violations of this sort, which occur as a by-product of socially productive government activity. After all, it is possible to imagine a world in which police were required to get fully litigated judicial approval before every search, never permitted to search in any doubtful case, required to forego any arrest that threatened to turn violent, and the like. The reason this is not our world must be that the compliance cost of never violating certain rights would be prohibitively high. Thus, it may be fair to describe the deterrence goal of constitutional tort damages as creating incentives for government to violate constitutional rights where, and only where, the compliance costs do not exceed some tolerable level, and to speak of an optimal level of (some types of) constitutional violations greater than zero.

This must be the basis for the conventional concern that, in the absence of official immunity, damages for constitutional torts will create overdeterrence. Courts and commentators seem to fear that, confronted with damages liability for all constitutional violations, government will take excessive precautions and incur extremely high compliance costs in order to avoid violations that would actually be socially optimal. ${ }^{75}$ Why government would respond to constitutional tort liability in this way remains a mystery, however. So long as the social benefits of constitutional violations exceed the compensable costs to the victim and are enjoyed by a majority of the population, compensation will never deter a majoritarian government from violating constitutional rights, because the majority of citizens will gain more from the benefits of government activity than they lose from the taxes necessary to finance compensation payments to victims. Adding compliance costs to the equation just makes the benefits to the majority of violating constitutional rights that much greater. If constitutional violations are not deterred by a compensation requirement where compliance costs are zero, then superoptimal violations-defined as those for which compliance costs are above some magnitude-certainly will not be either. Thus, contrary to the assumptions of courts and commentators about the effects of constitutional tort damages, a majority rule model predicts under-, not over-, deterrence, which qualified immunity for government officials would only exacerbate.

The only scenario in which constitutional tort damages could conceivably deter-let alone overdeter-a majoritarian government from violating constitutional rights would be one in which the compensated costs of the violation exceeded the social benefits-the sum of opportunity costs and compliance costs avoided. The analysis of this 
type of "inefficient" constitutional violation would at least superficially mirror the analysis of inefficient takings. ${ }^{76}$ Suppose, for example, that a local government is deciding whether to instruct its police officers to administer life-threatening chokeholds to suspects who resist arrest. Applying the chokehold in situations where the suspect's resistance did not present a threat of serious bodily injury to the arresting officers would, let us assume, violate the suspect's due process rights. At the same time, forbidding officers from using chokeholds would result in fewer successful arrests of dangerous criminals, more injuries to police officers, and perhaps reduced incentives on the part of the police officers to pursue suspects likely to resist arrest-with all of these effects contributing to some marginal increase in crime. Quite plausibly, the costs of permitting chokeholds, quantified in constitutional tort damages paid to people severely injured or killed by the police, would exceed the crime-reduction benefits. From the inefficient takings examples, we might conclude that, depending on the magnitude of the benefits to the majority, the size of the majority coalition, and the costs of unconstitutional searches to the minority, compensation will tend to reduce, but not eliminate, "inefficient" constitutional violations. To review, if the compensation costs of chokeholds inflicted on criminal citizens 1 and 2 equals $\$ 5000$ each, while the benefits in reduced crime to each of citizens 3-10 equals $\$ 500$ each, and if the tax burden to compensate citizens 1 and 2 is distributed equally among all ten citizens, then chokeholds will cost each of citizens 3-10 $\$ 500$ $(\$ 10,000$ in total constitutional costs divided by ten citizens $=\$ 1000$; subtract this from the $\$ 500$ in benefits) and each of citizens 1 and 2 $\$ 1000$. The citizens will vote ten to zero not to implement the chokehold policy. If the benefits in reduced crime are $\$ 1100$ for each of citizens $3-10$, however, then they will all support the policy (calculating $\$ 1100$ in benefits minus $\$ 1000$ in compensation costs).

Before concluding that the analysis of "inefficient" constitutional violations is the same as that of inefficient takings, however, we should note two important complications. For some types of "inefficient" constitutional violations, the social benefits will be enjoyed by the entire community, not just by a limited majority. In fact, the chokehold case may be an example, if citizen 1 is both the victim of a police

76 See text accompanying notes $59-68$.

77 Extending this analysis to other types of constitutional violations requires the assumption that these violations will also benefit a majority while concentrating costs on a minority. This seems realistic, at least for the categories of violations that generate constitutional tort litigation. Victims of police misconduct, public employees dismissed without adequate procedures, prisoners subjected to various abuses, and other common plaintiffs come in small numbers, whereas the benefits of the unconstitutional conduct tend to be shared broadly by consumers of government services and taxpayers. 
chokehold and a potential victim of crimes committed by citizen 2 . If all citizens share equally in the benefits of reduced crime and, given compensation for constitutional torts and equal tax burdens, in the costs of constitutional violations, then a majority will never support "inefficient" constitutional violations. (Note that there is still no overdeterrence problem, for only "inefficient" constitutional violations, not "efficient" ones, are deterred.) Not all "inefficient" constitutional violations will generate universal benefits in this way, however. For example, a state government that inflicts cruel and unusual punishment on prisoners, or violates their free exercise rights, may benefit the entire non-prison population by reducing their taxes while imposing only costs on the prisoners. In this case, as in the original chokehold example, constitutional tort damages will not always deter "inefficient" violations.

The second complication, which presents a serious difficulty for any analysis of the deterrent effects of constitutional tort damages, is that these damages are not calibrated to the social costs of constitutional violations. In practice, damages are available only for tort-like harms, such as property damage, medical expenses, pain and suffering, and emotional distress. ${ }^{78}$ Recovery is not permitted for the inherent value of constitutional rights, their value as public goods, ${ }^{80}$ the "expressive harms" inflicted by constitutional violations, ${ }^{81}$ the moral costs of breaching deontological prohibitions, third-party harms (such as those experienced by potential listeners of speech that is unconstitutionally suppressed), or any of the other conceivable harms to society that may occur when government violates constitutional rights. While there is no reason to accept current Supreme Court doctrine on the measure of constitutional tort damages as a fixed point, it is virtually impossible to imagine an alternative damages measure that could nonarbitrarily convert these types of intangible harms into dollars. If we accept that any realistic measure of compensation will fail to reflect

78 See Carey v Piphus, 435 US 247,257-59 (1978) (limiting recovery under Section 1983 to compensation for actual losses); Sheldon $\mathrm{H}$. Nahmod, Civil Rights and Civil Liberties Litigation: The Law of Section 1983, \& 4 (Shepard's 2d ed 1986 \& Supp 1989) (providing a comprehensive survey of damages rules under Section 1983).

79 See Memphis Community School District $v$ Stachura, 477 US 299, 305-10 (1986) (rejecting a claim that recovery should be available under Section 1983 for the abstract value of a constitutional right that has been violated).

80 See Joseph Raz, Ethics in the Public Domain: Essays in the Morality of Laws and Politics 29-44 (Clarendon 1994) (arguing that constitutional rights serve a collective interest in the preservation of various public goods).

81 See Richard H. Pildes, Why Rights are Not Trumps: Social Meanings, Expressive Harms, and Constitutionalism, 27 J Legal Stud 725 (1998) (arguing that much of constitutional law protects against "expressive harms"). See also Deborah Hellman, The Real Meaning of Equal Protection (unpublished draft on file with U Chi L Rev) (arguing that some types of equal protection violations are based on the expressive content of the state action). 
these costs, then calling constitutional violations "efficient" just because the social benefits exceed the compensable costs is potentially quite misleading. In fact, compensable costs are only a fraction of the true social costs. For that reason, a subset of violations that we have been calling "efficient" carry social costs that outweigh social benefits. Unless constitutional tort damages could somehow be made to reflect the full social costs, these violations will never be deterred by a compensation requirement. Yet presumably everyone-utilitarians and deontologists alike-would agree that they ought to be prevented. The underdeterrence problem, in other words, is greater than it may have first appeared.

This discussion only begins to reveal the difficulty of predicting the extent to which constitutional tort damages might deter constitutional violations and whether the level of deterrence is above, below, or equal to the socially optimal level. At the very least, however, the analysis does call into question the conventional prediction that constitutional tort damages will lead to overdeterrence in the absence of qualified immunity. If government decisionmaking is determined by majority rule, then underdeterrence would seem to be the prevalent concern.

\section{Summary.}

In the takings context, a simple majority rule model of the political process offers partial support for the conventional wisdom that just compensation prevents inefficient over-taking. The majority rule model also suggests that constitutional tort damages may deter some category of superoptimal constitutional violations. In contrast to the conventional wisdom that constitutional tort damages will tend to overdeter, however, the model predicts underdeterrence for most types of constitutional violations, even with the payment of compensation in every case. If a simple majority rule model were the end of the story, we might conclude, then, that constitutional cost remedies function more or less as the conventional wisdom would have it-less effectively and with different implications for qualified immunity in the constitutional torts context, but nevertheless generally exerting some deterrent pressure against undesirable government takings and violations of constitutional rights. Adding even quite modest complexity to the model of government behavior, however, undermines these results and suggests the difficulty of making any confident predictions at all.

\section{Interest Group Politics}

Straightforward majoritarian models of the political process coexist with models that assign a greater role to organized interest 
groups. ${ }^{82}$ So, let us consider the effects of constitutional cost remedies in a political system that has the following (additional) characteristics: (1) representatives are self-interested maximizers of their chances of reelection; (2) because of collective action problems, large groups of voters with diffuse interests tend to remain disorganized and relatively ineffectual politically; and (3) concentrated interest groups wield disproportionate political influence by offering representatives campaign contributions, blocks of votes, selective information, and the like, in exchange for favorable government policy. In such a system, as described by interest group theory, there is a systematic "tendency for the 'exploitation' of the great by the small." larger groups, especially majorities, have advantages of their own: obviously more votes, and perhaps also greater total resources. While interest group theory usually portrays majority groups as politically dormant and easily dominated by concentrated minority groups, in some situations - for instance, when information costs are low because an issue is highly publicized, per capita stakes are high, or costs are concentrated within the majority on potentially catalytic subgroupslarge groups can dominate small groups. ${ }^{\text {st }}$ Consequently, any plausible interest group theory must recognize that in a majoritarian electoral system, "exploitation of the great by the small" is limited by the potential "tyranny of the majority." Interest group theory should supplement, not supplant, the simple majority rule model, ideally by specifying the circumstances under which majorities will mobilize to defeat interest groups or vice-versa. Well developed models of political processes will integrate majoritarian and interest group components, based not only on the type of issue at stake but also on the level of government involved. ${ }^{85}$ The following discussion is comparatively simplistic, but hopefully at least suggestive of the outlines of a more sophisticated analysis.

82 Basic introductions to interest group theory and surveys of the primary literature include Daniel A. Farber and Philip P. Frickey, Law and Public Choice: A Critical Introduction 2137 (Chicago 1991); Einer R. Elhauge, Does Interest Group Theory Justify More Intrusive Judicial Review?, 101 Yale L J 31,35-44 (1991).

83 Mancur Olson, Jr., The Logic of Collective Action: Public Goods and the Theory of Groups 3 (Harvard 1st ed 1965) (emphasis omitted).

84 See Elhauge, 101 Yale L J at 39-40 (cited in note 82).

85 For illustrative attempts to integrate minoritarian and majoritarian models of politics based primarily on issues, see Komesar, Imperfect Alternatives at 65-97 (cited in note 60); James Q. Wilson, ed, The Politics of Regulation ch 10 (Basic 1980). Regarding levels of government, local governments are probably more majoritarian than state governments or the national government. See William A. Fischel, Regulatory Takings: Law, Economics, and Politics 253-62 (Harvard 1995) (surveying the literature). The failure of this Part to direct special attention to the special political process characteristic of local governments-combining Tiebout exit with majoritarian voice-is one of its more glaring omissions. It may well be the case that compensation for constitutional costs plays different roles at the local, state, and federal levels, but that hypothesis will not be examined here. 


\section{Takings.}

A first cut at interest group analysis in the takings context might point to the concentrated costs and relatively dispersed benefits characteristic of most takings, and hypothesize that interest groups would be more likely to form in opposition than in support. When government takes the property of one or several landowners in order to build a road or dam that will benefit the community at large, the condemnees will suffer concentrated costs and, because of their small numbers and geographical proximity, find it relatively easy to organize politically. The beneficiaries, on the other hand, may have small individual benefits at stake and confront high organization costs. If interest groups are likely to form in opposition to takings and exert disproportionate political influence, then, in the absence of a compensation requirement, we might expect government to engage in too few takings because the social costs would be politically inflated and the social benefits politically deflated.

Requiring just compensation for takings would shift the costs from concentrated groups of condemnees to some combination of two other groups: taxpayers or the beneficiaries of programs that would have to be defunded in order to cover the compensation costs. ${ }^{86}$ As between raising taxes and cutting spending, legislatures would choose the path of least political resistance. Assuming broad-based taxation to finance compensation, interest group pressure against takings would evaporate as the costs concentrated on politically efficacious condemnee groups were redistributed among the members of a politically inert majority. ${ }^{87}$ If the dispersed group of compensation taxpayers and the dispersed group of takings beneficiaries had roughly equivalent political influence, a compensation requirement would tend to equalize the political weights of costs and benefits and thereby produce efficient takings decisions. Likewise, if compensation costs were covered by defunding existing programs, legislatures would target programs whose beneficiaries would mount the least political resistance-perhaps programs with dispersed beneficiaries, possessed of political strength roughly equivalent to that of the takings beneficiaries. According to this simple model, then, commentators like Posner may be right about the efficiency-inducing effect of compensation but for precisely the wrong reason. Interest group theory suggests that without a compensation requirement government will under-take, not

86 See Daniel A. Farber, Public Choice and Just Compensation, 9 Const Comment 279,29293 (1992) (discussing different compensation regimes).

87 But see Levmore, 22 Conn L Rev at 308 (cited in note 12) (predicting intense political interest in taxes, either in the form of a mobilized majority or well organized interest groups). 
over-take, and that compensation forces government decisionmakers to internalize less of the social cost of takings, not more. ${ }^{\infty}$

For the very same reason, however, a compensation requirement should be superfluous. Assuming that government is independently motivated to minimize the political costs of takings, then it will pay compensation (and maybe over-compensation) voluntarily in a market transaction to which all affected property owners would consent. We certainly do not need a compensation requirement to force government to do what it will always choose to do anyway, namely minimize the political costs of its takings by redistributing the economic costs from concentrated interest groups to diffuse taxpayers or politically expendable beneficiaries of other government programs. ${ }^{90}$

A more nuanced interest group model would take into account that in many cases the beneficiaries of the taking will be more politically powerful than the condemnees. Interest groups or mobilized majorities will lobby for takings that generate benefits for themselves at the expense of individuals or small, unorganized groups lacking any other political bonds. For example, a homeowners association interested in increasing its property values by zoning a nearby adult entertainment club out of existence might enjoy considerable political advantages over the isolated club owner stemming from the association's slightly larger size and preexisting organization. This type of case raises the concern that government will over-take because social benefits are politically inflated and social costs politically discounted. Even if the homeowners would benefit only slightly from the removal of the club, and the club owner and customers would lose much more, ${ }^{91}$ the zoning commission might balance the political benefits of pleasing the homeowners association against the political costs of displeasing the club owner and decide that zoning would maximize political support.

88 Kaplow suggests in passing that the concentrated costs of takings may lead government to take.too little, but he then asserts, without explanation, that "[r]equiring compensation could only exacerbate this problem." Kaplow, 99 Harv L Rev at 569 (cited in note 11). Actually, requiring compensation will tend to solve the problem.

89 See Farber, 9 Const Comment at 292-93 (cited in note 86). Along similar lines, Professor Lunney argues that compensation should be required for takings that benefit a dispersed group at the expense of a concentrated group in order to avoid legislative mismatches that would tend to cause government to under-take. Glynn S. Lunney, Jr., A Critical Reexamination of the Takings Jurisprudence, 90 Mich L Rev 1892, 1954-59 (1992). But Lunney fails to recognize that insofar as compensation is a useful way for legislatures to co-opt concentrated interest groups opposed to takings, they will pay compensation voluntarily.

90 Interest group analysis may complement the suggestion, initially derived from a majoritarian model, of an economic role for the public use limitation on takings. See note 63 . By increasing the size of the groups benefited by takings, a reinvigorated public use requirement might tend to equalize the political power of beneficiaries and condemnees and thereby to increase the efficiency of takings.

91 Assume that the club would close permanently or relocate to an industrial neighborhood, so that there would be no offsetting decline in property values elsewhere. 
This is the sort of situation envisioned by commentators who defend the just compensation requirement as a deterrent to inefficient and unfair rent-seeking by dominant interest groups at the expense of the politically helpless. Saul Levmore, for example, argues that courts in takings cases should and do award compensation more readily where "occasional individuals" who cannot readily influence political bargains are on the losing end."

It is far from clear that mandatory compensation will correct a bias toward inefficient over-taking, however. A requirement of just compensation merely substitutes a relatively dispersed group of taxpayers or the beneficiaries of marginal, existing budget lines for the immediate regulatory loser. The question then becomes whether there is any reason to expect the level of political opposition to the revenue burdens imposed by compensated takings to exceed the level of opposition to the taking by uncompensated victims. As a general proposition, this seems doubtful. ${ }^{93}$ Certainly tax burdens concentrated on powerful interest groups, or cuts in other programs favored by such groups to free up funds for compensation, would trigger strong opposition. But again, rational elected officials will raise revenue from the least politically costly sources, such as broad-based taxation or minimal cuts in a number of programs supported by diffuse or otherwise weak groups. To be sure, if government continuously raises taxes, at some level the general tax burden will awaken the majority and incite political tax revolt. It is even possible that the visibility and political salience of compensation payments for inefficient projects would occasionally alert and catalyze a majority in opposition. But given that compensation is only a small fraction of the tax burden for any given voter, and taking into account fiscal illusion," which contributes to the high costs of obtaining information about the causes of marginal tax increases for dispersed voters, interest groups benefiting from takings may have little to fear in most political contests against larger groups of voters opposed to higher taxes. Compared to paying compensation, letting the costs of takings fall on condemnees might be expected to generate at least as much political opposition to takings, and therefore at least as much internalization of the social costs by elected officials.

92 See Levmore, 22 Conn L Rev at 305-19 (cited in note 12).

93 See Farber, 9 Const Comment at 290-94 (cited in note 86).

94 Fiscal illusion refers to strategies employed by the government to disguise citizens' true $\operatorname{tax}$ burden (and therefore the size of government). For a general discussion, see James $\mathrm{M}$. Buchanan, Public Finance in Democratic Process: Fiscal Institutions and Individual Choice 126-43 (North Carolina 1967); Charles J. Goetz, Fiscal Illusion in State and Local Finance, in Thomas E. Borcherding, ed, Budgets and Bureaucrats: The Sources of Government Growth 176 (Duke 1977); Mueller, Public Choice II at 342-43 (cited in note 57).

95 Again, for this reason we might expect government to pay compensation voluntarily in order to bribe the victims of takings to cooperate with programs that benefit other relatively 


\section{Constitutional torts.}

The effects of constitutional cost remedies on government behavior are even less clear, as one example should suffice to illustrate. Consider the interest group politics surrounding a police department's policy of aggressive questioning and searches of suspicious characters on the streets of high-crime neighborhoods. Insofar as constitutional tort damages are unavailable, victims of Fourth Amendment violations will bear the concentrated costs. As residents of high-crime, lowincome, often racial or ethnic minority neighborhoods, however, these victims are unlikely to be members of politically powerful interest groups. Even if close-knit communities of this sort could exert substantial political influence, they are unlikely to lobby vigorously for fewer constitutional violations against their residents for the simple reason that they also capture most of the benefits of crime prevention. ${ }^{36}$ The interests of a high-crime neighborhood as a political interest group are not the same as the interests of the narrower class of residents disproportionately victimized by constitutional violations. For example, young men who spend lots of time in the streets will bear the brunt of unconstitutional police harassment, whereas the majority of the neighborhood may be grateful for the orderly streets provided by the stepped-up police presence. The subclass of constitutional victims, standing alone, is not only low on the type of organization and resources that are useful in the political process, but they are also easily dismissed politically as consisting of likely criminals. Even when supported by sympathetic interest groups (like the ACLU), victims of constitutional violations probably wield little political influence. ${ }^{97}$ On the opposing side, in favor of greater police presence, it is also hard to think of a well organized interest group reliably in favor of more aggressive policing. Associations of business or property owners in highcrime neighborhoods might press for greater police protection, although insofar as these people are local residents, their interests may be counterbalanced by fears that extensive police presence will turn the neighborhood into "occupied territory." In light of the salience of crime as a political issue, majoritarian pressure to reduce crime and

powerful groups. Recognizing the prospect that compensation will thus allow government to over-take, Farber points out that efficiency might be better served by an anticompensation requirement. See Farber, 9 Const Comment at 291 (cited in note 86).

96 See Randall Kennedy, The State, Criminal Law, and Racial Discrimination: $A$ Comment, 107 Harv L Rev 1255, 1266-70 (1994); William J. Stuntz, Race, Class, and Drugs, 98 Colum L Rev 1795,1796 (1998) (suggesting that police policies that seem to discriminate against certain communities "may actually be a subsidy of those same communities, a redistribution of the services of the criminal justice system in their favor").

97 See William J. Stuntz, The Political Structure of Criminal Law (unpublished draft on file with U Chi L Rev). 
clean up the streets is almost certainly more relevant than the lobbying of any particular interest group.

Deriving any confident predictions about the level of constitutional violations from these scattered observations is impossible. But just for the sake of argument, let us hypothesize that majorities seeking to minimize crime while limiting their tax burden, supported by owners of businesses in high-crime communities and without substantial interest group opposition, successfully lobby for police tactics that cut constitutional corners. Suppose that these aggressive police tactics, consistent with the preceding discussion under the heading of majority rule, create a superoptimal level of rights violations in the absence of any compensation requirement. Adding compensation for constitutional torts would redirect the costs of constitutional violations from vulnerable subgroups in high-crime neighborhoods to taxpayers throughout the jurisdiction. Conceivably, this might ameliorate the hypothesized underdeterrence problem by forcing the beneficiaries of aggressive policing to bear a greater share of the costs.

On different, but no less plausible assumptions, however, the effect would be just the opposite. If aggressive policing disproportionately benefits high-crime, low-income communities (or their leadership), and especially if taxation is proportional or progressive, then these communities might be politically mobilized in favor of more aggressive policing. By buying off the subgroups within these communities who suffer the most from police aggression, compensation will encourage the community leadership to regard greater police presence as an unmitigated good. On the other side of the political tracks, the more affluent majority residing in low-crime neighborhoods will bear most of the tax burden of constitutional damage remedies while benefiting less from police services, and will therefore tend to favor more cautious police tactics. Given this political match-up, interest group theory might predict that the well organized, high-crime communities enjoying high per capita benefits of aggressive policing would exert greater political influence than the relatively dispersed majority suffering trivially higher per capita tax burdens. Mandating compensation for constitutional torts might therefore result in more constitutional violations, not fewer.

\section{Summary.}

Interest group analysis emphasizes the indeterminacy of the effects of compensation requirements on government behavior as a general matter, without detailed, contextual knowledge of the distribution of costs and benefits and the political strengths and weaknesses of affected groups. That said, the most consistent prediction generated by interest group analysis is that compensation for takings or constitu- 
tional torts will tend to defuse political opposition and therefore increase the incidence of both. Rather than predictably deterring socially undesirable takings and constitutional violations, compensation may tend to facilitate them. This possibility may seem radically counterintuitive against the background of the conventional literature, for it seems to suggest that raising the price of takings or constitutional violations in certain circumstances will somehow increase demand. But once we recognize that the relevant "price" is political, not economic, there is nothing especially surprising about it.

\section{Bureaucracy}

More sophisticated models of government decisionmaking will recognize that the connection between inputs, in the form of constituent preferences, and outputs, in the form of government policies, is more attenuated and far more complicated than the foregoing majority rule and interest group models suggest. Government is not a monolithic decisionmaker, but a multilayered collection of politicians and bureaucrats with different, and often conflicting, goals and agendas. In order to understand and predict how government agencies behave, we must take into account not only the agency relationship between elected officials and their constituents, but also the agency relationship between elected officials and bureaucrats. Majority rule and interest group theories focus on the incentives of reelectionmaximizing politicians. Much of the work of government, however, is carried out by bureaucrats who are not directly politically accountable. The police officers, prison guards, and high school principals who violate constitutional rights, along with the officials who staff the agencies that engage in takings to build highways or save wetlands may respond to constitutional cost remedies quite differently from how vote-maximizing legislators would prefer. The possibility of agency "slippage" or "drift" makes the consequences of constitutional cost remedies even more difficult to predict."

To illustrate, take the perspective of a high-level policymaking bureaucrat in the Environmental Protection Agency whose job it is to enforce the Endangered Species Act by prohibiting development on privately held farm land in California that is habitat to the tipton kan-

98 No, policing is not a Giffen good. See Hal R. Varian, Intermediate Microeconomics: A Modern Approach 103-06 (Norton 3d ed 1993) (defining "Giffen Good" as a good for which a decrease in price leads to a reduction in demand).

99 On the general phenomenon of bureaucratic drift, see Matthew D. McCubbins, Roger G. Noll, and Barry R. Weingast, Structure and Process, Politics and Policy: Administrative Arrangements and the Political Control of Agencies, 75 Va L Rev 431 (1989); Kenneth A. Shepsle, Bureaucratic Drift, Coalitional Drift, and Time Consistency: A Comment on Macey, $8 \mathrm{~J} \mathrm{~L}$, Econ, \& Org 111 (1992). 
garoo rat. The most commonly applied rational choice model, originally developed by William Niskanen, assumes that a policymaking bureaucrat will seek to maximize the size of her agency's budget. ${ }^{10}$ The size of an agency's budget, the theory goes, correlates positively with a number of other goods that bureaucrats probably value: the bureaucrat's own compensation and perquisites, prestige and prospects for career advancement, and even the influence of the agency in accomplishing its substantive goals, to which the bureaucrat may be ideologically committed. ${ }^{101}$ So let us hypothesize that the EPA bureaucrat is solely concerned with maximizing the agency's budget. How will the bureaucrat's behavior be affected by a requirement of compensation for "habitat takings"? ${ }^{102}$

Suppose that the bureaucrat is faced with a choice between two parcels of land that might be taken and reserved for kangaroo rat breeding: 500 acres of $\$ 200$ /acre prime farm land or 1000 acres of $\$ 100 /$ acre mediocre farm land. Suppose further that compensation for habitat takings comes out of the agency's budget. Society would be better off if the agency took the less expensive, mediocre farm land, which would provide more acres of breeding ground per dollar. If the bureaucrat chooses to take the less expensive land, the agency's output (measured in acres of kangaroo rat habitat or number of surviving kangaroo rats) will be higher than if she takes the more expensive land. But the bureaucrat makes a different kind of calculation. Her goal is not to maximize social welfare or agency output; it is to maximize budget.

The Niskanen model assumes that the congressional committees and high-level executive officials who oversee the agency and control its appropriations (the agency's "sponsors") have the ability to monitor the agency's output, but not its cost schedule, which only the bureaucrat herself knows. ${ }^{103}$ If the bureaucrat confronts the sponsor at the time of appropriation with low output ( 500 acres taken) at budget level $B(\$ 100,000)$ as a result of consistently taking more expensive land, the sponsor might decide to increase the budget of the agency in order to raise output to the desired level. If so, the agency would have the potentially perverse incentive to maximize the value of property taken for habitat. Then again, the sponsor might decide that the agency's meager output was not worth the cost and that there were

100 See William A. Niskanen, Jr., Bureaucracy and Representative Government $36-42$ (Aldine 1971).

101 Id.

102 For a general discussion of the issue of habitat takings under the Endangered Species Act, see Robert Innes, Stephen Polasky, and John Tschirhart, Takings, Compensation and Endangered Species Protection on Private Lands, 12 J Econ Persp 35 (1998).

103 See Niskanen, Bureaucracy and Representative Government at 24-30 (cited in note 100). 
greater political benefits to be had by spending at least part of the agency's budget elsewhere-on the work of other agencies or on different projects within the EPA. Without knowing anything about the incentives of the sponsors, either result seems equally plausible. Forcing the agency to pay compensation, therefore, will not necessarily encourage efficient takings, and may actually encourage inefficient ones.

Other assumptions about bureaucratic behavior lead in different, albeit equally indeterminate, directions. Suppose, for example, that compensation for habitat takings comes not from the agency's budget but from a general judgment fund. ${ }^{104}$ If the bureaucrat regarded compensation payments as de facto additions to the agency's budget, then a compensation requirement would once again create the potentially perverse incentive to take the most expensive property. Or maybe not, if the agency's sponsors could easily monitor the agency's draw on the judgment fund and, knowing its output, discover the agency's inefficiency and punish it by defunding.

And what if we substitute alternative assumptions about the agency's maximand? Suppose that instead of maximizing the size of her agency's total budget, the bureaucrat seeks to maximize her discretionary budget, the difference between the total budget and the minimum cost of producing the agency's outputs. ${ }^{105}$ If the agency must produce a fixed level of output measured in acres of wetlands protected for a fixed budget each term, and compensation for taking wetlands comes out of the agency's budget, then the bureaucrat will have an incentive to make efficient takings decisions. ${ }^{106}$ She will choose to take the $\$ 100 /$ acre land rather than $\$ 200 /$ acre land because this will enable her to achieve the fixed level of output for a lower cost, leaving more money in the fixed budget for her to spend on discretionary projects or perquisites. Then again, suppose that the bureaucrat seeks to maximize not total or discretionary budget, but leisure. ${ }^{1.7}$ If the pro-

104 See Cass, 129 U Pa L Rev at 1176 (cited in note 22). Ordinarily, compensation for litigated takings by the federal government is paid out of the Judgment Fund, a permanent appropriation established by 31 USC $\$ 1304$ (1994). See Royal C. Gardner, Banking on Entrepreneurs: Wetlands, Mitigation Banking, and Takings, 81 Iowa L Rev 527, 550 n 157 (1996) (describing the Judgment Fund). For a general discussion of the choice between funding compensation from the federal Judgment Fund or from an agency's budget, see Charles Tiefer, Controlling Federal Agencies by Claims on Their Appropriations? The Takings Bill and the Power of the Purse, 13 Yale J Reg 501 (1996).

105 See Jean-Luc Migué and Gérard Bélanger, Toward a General Theory of Managerial Discretion, 17 Pub Choice 27 (1974) (describing how bureaucrats try to maximize discretionary funds); Paul Gary Wyckoff, The Simple Analytics of Slack-Maximizing Bureaucracy, 67 Pub Choice 35 (1990) (same).

106 Of course, if the compensation is paid out of a general fund, then she will be indifferent as to the takings price of land.

107 See Kenneth A. Shepsle and Mark S. Bonchek, Analyzing Politics: Rationality, Behavior, and Institutions 354 (Norton 1997). 
cess of designating kangaroo rat habitats constitutes the bureaucrat's workload and each acre so designated requires a positive increment of work, then the bureaucrat might choose to take the most expensive land in order to exhaust the agency budget while minimizing her workload. Depending on the relevant assumptions about bureaucratic behavior and the factual context, compensation could create efficient incentives, inefficient incentives, or no incentives at all.

Even if we could figure out what the relevant bureaucrats would maximize if left to their own devices, this is only one variable in predicting agency actions. As the preceding discussion of agency-sponsor interaction should remind us, bureaucrats are not, in fact, left to their own devices. Rather, they are supervised, more or less successfully, by their legislative (and executive) principals, who exercise control over agencies by drafting and revising statutes governing agency authority, authorizing appropriations, and monitoring agencies' activities. ${ }^{108}$ In order to make predictions about bureaucratic outputs, therefore, we first need to understand not just the incentives of the bureaucrats, but also the incentives of the relevant legislative oversight committees ${ }^{109}$ and high-ranking executives, who constitute different, and often competing, constituencies. Equally important is the way these incentives are aggregated through voting rules and bargaining."

Further, once the incentives of agency bureaucrats and their sponsoring legislative-executive coalition are understood, determining the resulting agency behavior requires application of some model of sponsor-agency oversight and strategic interaction. Different models will often predict quite different results. The extent to which agency actions are aligned with the preferences of their legislative and executive principals depends on how successful these principals are at monitoring agencies to detect noncompliance. This, in turn, depends on the effectiveness and availability of monitoring strategies, such as direct "police patrol" supervision or "fire alarms" sounded by constituencies affected by agency action when they detect agency misbehavior."

108 See James Q. Wilson, Bureaucracy: What Government Agencies Do and Why They Do It 235-56 (Basic 1989) (describing the relationship between Congress and federal agencies).

109 Every federal agency must answer to at least four congressional committees: the House and Senate committees that authorize the agency and specify its substantive mission, and the House and Senate appropriations committees that determine the size of its budget and staff. Id at 256 . Some agencies are subject to incredibly fractured oversight. See id at 244 (noting that 29 committees and 55 subcommittees have some oversight responsibility for the Defense Department).

110 For an example of a model incorporating all of these actors, plus courts, see John Ferejohn and Charles Shipan, Congressional Influence on Bureaucracy, 6 J L, Econ, \& Org 1 (Supp 1990).

11 See Arthur Lupia and Mathew D. McCubbins, Learning From Oversight: Fire Alarms and Police Patrols Reconstructed, 10 J L, Econ, \& Org 96 (1994); Mathew D. McCubbins and Thomas Schwartz, Congressional Oversight Overlooked: Police Patrols versus Fire Alarms, 28 Am 
Agency control also depends on the effectiveness of the rewards and sanctions available to legislative and executive principals for use in redirecting the activity of noncompliant agencies, including appointments, legislative mandates, structure, procedures, or budget.12 Not surprisingly, given the number and complexity of variables involved, plausible approaches to modeling agency oversight run the gamut from those assuming agencies will ordinarily be able to dupe their sponsors, ${ }^{113}$ to those assuming greater parity between sponsor and agency, ${ }^{114}$ to those assuming sponsor dominance. ${ }^{115}$ These different models will yield different predictions about agency outcomes from a given set of principal and agent incentives.

To complicate matters still further, agency costs are present not just in principal-sponsor interactions but also within the agency, in manager-employee interactions. The fact that managerial bureaucrats have settled on a particular policy does not mean that lower-level officials will implement that policy in perfect conformity with managerial design. Street-level officials will often have the incentives and means to pursue their own objectives, which may well deviate from managerial preferences.

In fact, this is the one insight about governmental incentives that the literature on constitutional tort damages seems to have taken fully to heart. As discussed previously ${ }^{116}$ courts and commentators are convinced that monetary damage awards leveled against street-level officials will lead to overdeterrence. Because these officials do not internalize the benefits of their activities, the standard argument goes, the threat of personal liability for constitutional torts will cause them to minimize private costs by steering well clear of activities that carry risks of liability-even if the social benefits of these activities would outweigh the social costs.

Suppose that a police commissioner recognizes this potential overdeterrence problem but is motivated to maintain a socially optimal level of aggressive policing. (Where might this motivation come from? Imagine that majoritarian or interest group politics have made

\footnotetext{
J Polit Sci 165 (1984) (identifying different types of congressional oversight).

112 For a general discussion of congressional means of controlling agencies, see Murray J. Horn, The Political Economy of Public Administration: Institutional Choice in the Public Sector 68-78 (Cambridge 1995); Wilson, Buréaucracy at 237-41 (cited in note 108); McCubbins, Noll, and Weingast, 75 Va L Rev 431 (cited in note 99).

113 See, for example, Niskanen, Bureaucracy and Representative Government at 24-30 (cited in note 100$)$.

114 See, for example, Gary J. Miller and Terry M. Moe, Bureaucrats, Legislators, and the Size of Government, 77 Am Polit Sci Rev 297, 301-22 (1983).

115 See, for example, Barry R. Weingast and Mark J. Moran, Bureaucratic Discretion or Congressional Control? Regulatory Policymaking by the Federal Trade Commission, $91 \mathrm{~J}$ Polit Econ 765 (1983).

116 See text accompanying notes 16-24.
} 
this the reelection maximizing strategy for city council members, who in turn have promised the police commissioner a larger budget in exchange for cracking down on street disorder.) The commissioner will attempt to adjust the incentives of street-level officers using a variety of carrots and sticks. For example, the department may indemnify officers against personal liability and the costs of defending themselves at trial (a routine, real-life strategy), while also offering rewards, in the form of bonuses or promotions, for aggressive police work (lots of street searches, arrests, and the like). Unfortunately for the commissioner, however, certain characteristics of government bureaucracy may impede efforts to structure incentives by limiting the carrots and sticks at her disposal. Civil service laws, for instance, limit the discretion of bureaucratic managers over wages, benefits, promotions, and terminations of employees. ${ }^{117}$ (Although these laws are obviously not exogenous to government, in practice they are sufficiently well entrenched that bureaucratic managers must accept them as given. ${ }^{118}$ ) In addition, managers of public agencies that produce outputs that are difficult to observe and quantify, like police departments, will have a difficult time monitoring the activity of subordinates."

The manager of a private security service facing similar agency problems has at least two important advantages that highlight the corresponding disadvantages of the public manager. First, market signals will offer the private manager valuable information that the public manager lacks. If clients disappear and revenues fall off, the private manager will have an incentive to investigate the performance of officers and, perhaps, to discover that they have been overly passive on the beat. Second, the private firm will have far greater latitude to structure the incentives of its security guards by, for example, promoting aggressive guards and firing those suspected of shirking. ${ }^{120}$ For public agencies, therefore, significantly more so than for private firms, the behavior of low-level officials may diverge from the policy preferences of high-level decisionmakers.

It is important to recognize, however, that just because managers cannot elicit perfect compliance from their agents does not mean that the agents will behave just as they would in the absence of any managerial control. Imprecise managerial incentives are not equivalent to no incentives at all. If the police commissioner believes that officers

117 See Horn, Political Economy of Public Administration at 95-133 (cited in note 112); Cass, $129 \mathrm{U}$ Pa L Rev at 1166-71 (cited in note 22).

118 For a theory of why it is in the interest of legislators to maintain civil service employment rules that tie their own hands when it comes to controlling subordinates, see Horn, Political Economy of Public Administration at 95-133 (cited in note 112).

119 See Wilson, Bureaucracy at 168-71 (cited in note 108).

120 See id at 113-36, 169 (identifying constraints on public managers). 
are not being sufficiently aggressive even after they have been fully indemnified against constitutional tort liability, she may try to create rewards for aggressive tactics. Because outcomes of aggressive policing, like orderly streets, may be difficult to observe and impossible to attribute to officers' behavior, the commissioner may tie these rewards to observable (but imperfect) proxies, such as number of searches or arrests. Depending on the relative magnitude of these rewards and the residual aversion to being sued for constitutional torts, individual officers might then have incentives to perform too many unconstitutional searches or arrests. If the commissioner had perfect control, let us suppose, officers would search and arrest only when the expected social benefits-measured in reducing street disorder and, ultimately, crime-outweighed the expected social costs of searches and arrests on the wrong side of the constitutional line. ${ }^{21}$ But because it is impossible for the commissioner to determine whether any particular search and arrest is cost-benefit justified, she will not be able to distinguish searches and arrests that should be rewarded from those that should not. Taking into account the blunt instruments for rewarding good behavior and sanctioning bad behavior at the commissioner's disposal, any incentive system directed at street-level officers is likely to be highly imperfect-it will overdeter, underdeter, or some of both. Thus, even if the managers of an agency are motivated to direct the agency to engage in socially optimal behavior, if the agency's activities must be implemented by street-level officials with discretion, there is no guarantee that socially optimal behavior will result and no way of easily ascertaining in which direction deviations will occur.

All of this suggests the complexity of determining the effect of constitutional cost remedies on the ultimate behavior of bureaucratic officials-the individuals who act in the name of government and whose behavior constitutional cost remedies are supposed to affect. Determining the effect of a compensation requirement on the incentives of elected officials using majoritarian or interest group models is difficult enough, as the earlier sections demonstrated. But that is only the first step in predicting government behavior. The incentives of bureaucratic managers and street-level officials must also factor into the predictive equation, as must the bargaining and agency relationships among all of these actors. Needless to say, the more moving parts and debatable assumptions added to the overall model of government outcomes, the less confident we can be in making even highly contextual predictions about the effects of requiring compensation. Yet without a sufficiently complex model, any predictions about the incen-

121 This is controversial for the reasons discussed above, in the text accompanying notes 69- 
tive effects of constitutional cost remedies on government behavior are highly suspect.

\section{COMPENSATION WITHOUT DETERRENCE}

The moral of Part II is that the incentive effects of constitutional cost remedies are, as a general matter, simply indeterminate-perhaps as likely to be perverse as beneficial. In order to predict how government will respond when forced to pay money, we must construct a model of government behavior out of competing and controversial assumptions and empirical conjectures. Any model sufficiently complex to generate reasonably precise predictions will depend on quite rigid and context-specific assumptions that will severely limit its applicability. This is not to dismiss the possibility that further work will enable more generalizable predictions; to the contrary, one motivation for this Article is to direct scholarly attention to the relationship between economic and political costs in the hope of better understanding how government incentives can be shaped by constitutional remedies. Nonetheless, at present, we should have little confidence in any of the conventional assumptions about the deterrent effects of making government pay money for constitutionally significant harms (or for anything else).

For some readers, the failure of constitutional cost remedies to deter will be nearly dispositive of their usefulness. Others, however, will emphasize various intuitive non-deterrence benefits of compensating victims as an independent justification for making government pay. If we do not compensate the victims of takings, for example, perhaps people will hesitate to make socially productive investments. And, setting efficiency aside, perhaps it would be unfair, immoral, or unjust to inflict uncompensated losses on the victims of takings and constitutional torts. Readers inclined to think that constitutional cost remedies are clearly justified by non-deterrence rationales such as these may be inclined to worry less about the absence of any convincing deterrence rationale.

These readers should not be let off the hook so easily, however. Because the deterrent effects of making government pay have been so universally taken for granted, other rationales for compensation have not been subject to nearly as much critical examination as they deserve. A closer look at the leading non-deterrence justifications for compensating the victims of takings and constitutional torts reveals that they are far from obvious or noncontroversial.

This Part explores both efficiency consequences and justice concerns that might be thought to justify constitutional compensation requirements. Needless to say, a conclusive assessment of the nondeterrence rationales for compensation is well beyond the reach of 
this Article. But even a cursory survey reveals serious weaknesses and gaps in all of the commonly asserted efficiency and justice justifications for compensating the victims of takings and constitutional torts. Forced to stand alone rather than as accessories to deterrence, these justifications suddenly seem rather wobbly. It is far from clear that they can bear the entire weight of constitutional cost remedies once the crutch of deterrence has been removed. The significance of deterrence, consequently, cannot so easily be discounted.

\section{A. Takings}

The discussion in this Section questions the adequacy of nondeterrence justifications for the just compensation requirement. These justifications for compensation break down into arguments from efficiency and from justice. ${ }^{12}$

Let us begin with efficiency. Although the economic efficiency case for compensating takings usually emphasizes the incentive effects on government officials, ${ }^{123}$ that is not the only argument. Two other efficiency arguments have been developed in the literature, each based on the incentives and welfare effects of just compensation on private actors.

In his foundational article on takings, Frank Michelman argues that compensation for takings is justified (within a utilitarian framework) in cases where the costs of not compensating exceed the costs of paying compensation. " The costs of not compensating, which Michelman refers to as "demoralization" costs, include the reduced incentives of private persons to invest in capital improvements to property that is at risk of being taken by the government. ${ }^{125}$ Growing out of Michelman's approach is the argument that compensation for

122 See Heller and Krier, 112 Harv L Rev at 998-99 (cited in note 9).

123 Several leading economic analyses point to government incentives as the strongest argument for the just compensation requirement. See Posner, Economic Analysis of Law at 63-67 (cited in note 6); Fischel and Shapiro, 9 Intl Rev L \& Econ 115 (cited in note 65); Cooter, 73 Cal L Rev at 19-25 (cited in note 9).

124 See Michelman, 80 Harv L Rev at 1214-18 (cited in note 8). Michelman would altogether bar takings for which both the costs of paying compensation and the costs of not paying compensation exceed the social benefits. Id at 1215 .

125 Michelman defines demoralization costs as

the total of (1) the dollar value necessary to offset disutilities which accrue to losers and their sympathizers specifically from the realization that no compensation is offered, and (2) the present capitalized dollar value of lost future production (reflecting either impaired incentives or social unrest) caused by demoralization of uncompensated losers, their sympathizers, and other observers disturbed by the thought that they themselves may be subjected to similar treatment on some other occasion.

Id at 1214 (internal footnotes omitted). This definition seems to include not just this underinvestment effect, but also less tangible psychological and social costs. See Fischel, Regulatory Takings at 148-50 (cited in note 85). 
takings is justified in order to prevent inefficient underinvestment in property by private individuals. Property owners will rationally discount the expected value of property investments by the risk of uncompensated takings and therefore limit their investments to suboptimal levels. ${ }^{126}$ As subsequent commentators have pointed out, however, the noncontroversial observation that the risk of uncompensated takings will reduce private investment does not mean that the reduced level of investment is suboptimal and can be counted as an efficiency cost. To the contrary, guaranteed compensation for takings would lead to overinvestment in capital improvements. This is because fully indemnified property owners would disregard the risk that improvements would be made valueless by a government taking. Quite the opposite of solving an underinvestment problem, compensation creates a moral hazard problem of overinvestment. ${ }^{12}$

A simple example will illustrate the point. Developer must decide whether to invest $\$ 1$ million in building an office tower on her land. At the time of her decision, the city council is debating whether to route a new highway through Developer's land or through a neighboring parcel. If the highway is run through the neighboring land, Developer's office tower will be worth $\$ 1.5$ million; if the city council takes Developer's own property for the highway, the office tower will have zero value, because it will have to be torn down. ${ }^{128}$ If there is an objective 50 percent chance that the city council will decide to take Developer's property for the highway, the socially optimal result is for Developer to hold off on building the office tower: the expected cost of the building project ( $\$ 1$ million) exceeds the expected benefit $(0.5 \mathrm{x}$ $\$ 1.5$ million $+0.5 \times \$ 0=\$ 750,000$ ). If Developer knows she will be fully compensated for the value of the office tower in the event her land is taken, however, she will not discount the benefits of the building project by the probability of the taking. Because the tower will be worth $\$ 1.5$ million whether it is sold in a market or "sold" to government through the payment of just compensation, the benefits of the building project will exceed the costs, and Developer will proceed to build. $^{129}$ If, on the other hand, Developer knows she will not be com-

126 In addition to Michelman, see William F. Baxter and Lillian R. Altree, Legal Aspects of Airport Noise, $15 \mathrm{~J}$ L \& Econ 1, 2-5 (1972); Lawrence Berger, A Policy Analysis of the Taking Problem, 49 NYU L Rev 165,195-206 (1974).

127 See Kaplow, 99 Harv L Rev at 527-36 (cited in note 11); Cooter, $73 \mathrm{Cal} \mathrm{L} \mathrm{Rev} \mathrm{at} \mathrm{20-21}$ (cited in note 9).

128 Actually, taking into account the costs of demolition, the value will be negative. But let us stick with zero for the sake of simplicity.

129 This assumes, as throughout the Article, that just compensation equals market value. Although this is a close enough approximation for present purposes, it will not always be true in practice. See Patricia Munch, An Economic Analysis of Eminent Domain, $84 \mathrm{~J}$ Polit Econ 473, 495 (1976) (reporting the empirical result that high-value parcels receive more than fair market 
pensated for the taking, her cost-benefit analysis will reflect the full social costs and benefits, and she will decide not to build. In general, because the efficient level of private investment will result only if investors internalize the full social costs and benefits of their decisions, they should not be protected from the costs of wasted investment due to takings. Just as generous disaster relief for flood victims encourages over-building on flood plains, and International Monetary Fund bailouts encourage too much borrowing and fiscal irresponsibility by debtor nations, full indemnification for takings condemnees encourages overinvestment in property.

A limited, but important, exception to this conclusion applies to takings in which the government intends to make productive use of the capital improvement rather than simply destroying it. ${ }^{130}$ For example, if the city council plans to take Developer's office building to use as the new police headquarters, then Developer should be compensated, at least in part, for the lost building so that she will internalize the positive social benefits of its construction. ${ }^{131} \mathrm{~A}$ rational and efficient government with a long time-horizon might voluntarily purchase goods for productive use in order to avoid shortages. If the city council routinely conscripts new office buildings without paying compensation, then fewer office buildings will be constructed in the first place, and the city council will find itself worse off in the long run. But given that government decisionmaking is not predictably rational or efficient, a constitutional requirement of compensation might be justified on efficiency grounds. At most, however, this argument supports a compensation requirement limited to cases where the investment conscripted by government is used to generate public benefits and is of elastic supply. In the majority of takings cases, where government is conscripting land, forbidding development, or regulating use of property, there is no concern with maintaining the supply of productive capital available to government.

The second efficiency justification for just compensation is closely related to, but conceptually distinct from, the first. Compensation for takings might be justified, the argument goes, as a form of insurance for risk-averse property owners. ${ }^{1.2}$ Without compensation for takings, risk-averse property owners will discount the value of property and improvements, not only by the expected loss of a taking, but also by the premium they would charge for bearing the risk of that loss. Risk

\footnotetext{
value and low-value parcels less).

130 See Kaplow, 99 Harv L Rev at 529-30 n 54 (cited in note 11); Susan Rose-Ackerman, Against Ad Hocery: A Comment on Michelman, 88 Colum L Rev 1697, 1702-03 (1988).

131 If the building is worth only $\$ 750,000$ as a police headquarters, then, ideally, that should be the amount of Developer's compensation.

132 See Blume and Rubinfeld, 72 Cal L Rev at 571-73 (cited in note 9).
} 
aversion can lead to socially inefficient investment decisions, as the following example illustrates.

Suppose that Developer is choosing between two sites for construction of an office building, north and south. If Developer builds on the north parcel of land, the completed building will be worth $\$ 1$ million; if she builds on the south parcel, which costs exactly the same amount as the north parcel, the building will be worth $\$ 2.2$ million. Developer knows that there is a 50 percent chance that, after construction of the building has been completed, government will rezone or impose an environmental regulation on the south parcel such that the building, if located there, would be rendered worthless. There is no chance that the government will rezone or regulate the north parcel. If Developer is risk neutral, she will choose to develop the south parcel, for the expected value of the building there $(0.5 \times \$ 2.2$ million $+0.5 \times$ $\$ 0=\$ 1.1$ million) is greater than the certain value of the building on the north parcel (\$1 million). If Developer is risk averse, however, she will discount the expected value of building on the south parcel by some risk premium. If this premium exceeds $\$ 100,000$, Developer will choose to develop the north parcel instead.

If insurance were available to spread Developer's risk, however, she would gladly pay the premiums and choose the efficient investment. Actuarially fair insurance on the developed south parcel, providing full indemnification in the event of a taking, would cost Developer $\$ 1.1$ million in premiums (equal to the expected loss, or $0.5 \times \$ 2.2$ million), but in exchange she would be certain of realizing the building's full value, $\$ 2.2$ million. Insurance would thus eliminate Developer's risk premium, and with it the possibility that she would choose less socially valuable projects. Lawrence Blume and Daniel Rubinfeld argue that just compensation for takings serves precisely this insurance function. ${ }^{133}$ Property owners pay insurance premiums in the form of taxes, and in exchange are indemnified by the government for losses that result from takings. By spreading the risk of takings among all taxpayers, just compensation eliminates the investment distortions caused by risk aversion. The result is improved allocative efficiency, as resources are employed in higher-value uses.

Blume and Rubinfeld are surely correct that insurance against takings could play an important role in enhancing efficiency. It is doubtful, however, that providing insurance through across-the-board just compensation makes economic sense. One problem is that only risk-averse property owners benefit from takings insurance. Not all people are property owners, and not all property owners are riskaverse. So, ideally, just compensation - and the taxes exacted to fi-

133 Id at 590-99. 
nance it-should apply only to the class of risk-averse property owners. Forcing non-property owners to pay premiums effects an arbitrary, and probably regressive, transfer to property owners. Further, assuming that some administrative cost will be built into tax "premiums," risk-neutral property owners (such as corporations) are also disadvantaged by a generally applicable, tax-financed just compensation scheme. The administrative costs of singling out risk-averse property owners for taxation and compensation, or, more likely, the error costs of forcing insurance on non-property owners and non-risk-averse property owners who would not choose to purchase it in the private market, might well outweigh the efficiency benefits of insurance. ${ }^{134}$

Furthermore, the risk-spreading benefits of just compensation must be balanced against the moral hazard costs addressed above. ${ }^{135}$ Owners who are fully indemnified against takings have an incentive to overinvest in property that is at risk of being taken. Thus, the efficiency of just compensation depends on the relative magnitudes of the underinvestment incentive created by risk aversion and the overinvestment incentives created by the moral hazard accompanying indemnification. In the absence of any further information about the magnitudes of these effects, there is no reason to expect the insurance benefits of just compensation to outweigh the moral hazard costs. Just compensation may be more, less, or just as efficient as no compensation.

These two objections to the insurance justification for just compensation come together in a broader challenge: Louis Kaplow asks why we should resort to government-provided takings insurance rather than relying on the private market. ${ }^{136}$ Private insurance would have the obvious advantage of limiting coverage (and premium bills) to risk-averse parties who would be made better off by riskspreading. ${ }^{137}$ Private insurance would also have important advantages in balancing the benefits of risk-spreading against the costs of moral hazard created by indemnification. ${ }^{123}$ Because private insurance premiums would be calibrated to expected losses, policyholders would be forced to internalize the expected cost of takings-costs they would be able to externalize onto other taxpayers in a world of government indemnification with premium rates disconnected from risk. In theory,

134 Blume and Rubinfeld recognize and attempt to negotiate this difficulty, but with limited success. Id at $600-10$.

135 See text accompanying notes 126-29.

136 Kaplow, 99 Harv L Rev at 536-50 (cited in note 11).

137 It is conceivable, but unlikely, that mandatory coverage would be the best possible solution to adverse selection problems that might otherwise threaten to unravel the risk pool. See id at 545 .

138 Id at $537-41$. 
courts and legislatures might attempt to combat moral hazard by adjusting the level of compensation. Blume and Rubinfeld suggest, for example, that government might calculate compensation amounts based on the value of the property as the owner would have developed it if she had not expected the government to pay compensation. ${ }^{139}$ In practice, however, such a determination would be all but impossible. In contrast, private insurance companies routinely manage moral hazard effectively by adjusting premiums, and by adding deductibles, exclusions, and the like to insurance contracts. If we had to bet on whether government, through a just compensation system, or the market, through private insurance contracts, would manage more efficiently to balance risk-spreading and moral hazard, the choice seems clear. ${ }^{140}$

In sum, once government incentives are off the table, the remaining efficiency case for a just compensation requirement is highly dubious. From an efficiency perspective, a rule of no compensation seems at least as plausible as a rule of full or partial government compensation.

Efficiency and wealth-maximization are not the only values just compensation might serve, however. Courts and commentators often discuss compensation for takings in terms of justice or fairness. ${ }^{141} \mathrm{Un}$ fortunately, most of these discussions begin and end with superficial assertions about the unfairness or injustice of picking on a few unfortunates for the benefit of the public at large. Perhaps better-developed arguments from moral or political philosophy could persuasively demonstrate the wrongness or injustice of taking property without just compensation, but to do so would require overcoming some difficult objections. While an extended discussion of what morality or justice requires with respect to takings is far beyond the scope of this Article, it may be worth at least suggesting some reasons for skepticism about fairness- or justice-based defenses of the just compensation requirement.

139 See Blume and Rubinfeld, $72 \mathrm{Cal} \mathrm{L}$ Rev at 618-20 (cited in note 9).

140 See Kaplow, 99 Harv L Rev at 536-50 (cited in note 11) (arguing that private market mechanisms are "generally superior" to government). Even if it were true that the just compensation mechanism could outperform private insurance and deliver risk-spreading benefits that outweighed moral hazard costs, these efficiency benefits would still have to be balanced against at least two further costs. First, the revenues for paying just compensation must be raised through taxes, and taxation will add some degree of allocative inefficiency. See Posner, Economic Analysis of Law at 65,523-24 (cited in note 6). Second, the administrative costs of calculating compensation and distributing payments-what Michelman refers to as "settlement costs"-must be subtracted from any gains. See Michelman, $80 \mathrm{Harv}$ L Rev at 1214 (cited in note 8).

141 See Heller and Krier, 112 Harv L Rev at 998-99 (cited in note 9) (recognizing a "virtual consensus" in the takings literature -including judicial opinions and academic commentarythat the two primary purposes of just compensation are efficiency and justice). Of course there are theories of justice, such as utilitarianism, for which efficiency is a highly relevant criterion. 
The leading noninstrumental argument in support of compensation proceeds from a principle of political equality or antidiscrimination: the government should not be allowed to single out a small minority to bear the costs of public benefits. As the Supreme Court often puts it, government must not "forc[e] some people alone to bear public burdens which, in all fairness and justice, should be borne by the public as a whole. ${ }^{142}$ Similarly, Laurence Tribe offers the descriptive theory that just compensation expresses "a limit on government's power to isolate particular individuals for sacrifice to the general good," based on the principle that "society simply should not exploit individuals in order to achieve its goals."143 And while Michelman's more sophisticated discussion of the fairness of just compensation purports to apply a Rawlsian theory of distributive justice, ${ }^{1+4}$ it arguably also rests on the understanding that the unfairness of uncompensated takings lies in the arbitrary imposition of selective burdens on the few for the benefit of the many.

It seems inevitable, however, that any theory along these lines will prove either too much or too little: too much, because virtually every law or government policy "singles out" some to bear a disproportionate burden for the benefit of others; too little, because insofar as the ultimate goal is distributive justice among citizens, focusing narrowly on particular redistributions without taking into account the background distribution of wealth or entitlements seems arbitrary and futile. Let us consider these objections in turn.

Surely the problem with uncompensated takings cannot just be that every government action must treat all citizens the same. Every law discriminates, in the sense of distributing benefits and burdens unequally. ${ }^{146}$ If the problem is supposed to be state actions that benefit relatively large groups at the expense of relatively small groups, we might wonder why the same problem does not arise with respect to the unfortunate few placed in the highest tax bracket, the neighborhood that endures increased crime rates when police services are reallocated elsewhere, the workers who get laid off as a result of free-

142 Armstrong v United States, 364 US 40, 49 (1960). See also First English Evangelical Lutheran Church v County of Los Angeles, 482 US 304, 318-19 (1987); Penn Central Transport Co $v$ New York City, 438 US 104, 123 (1978).

143 Laurence H. Tribe, American Constitutional Law 605 (Foundation 2d ed 1988).

144 See Michelman, 80 Harv L Rev at 1218-24 (cited in note 8) (drawing on work that would soon become John Rawls, $A$ Theory of Justice (Belknap 1971)).

145 Michelman's evaluation of the fairness of uncompensated takings turns on whether the immediate losers are likely to be better off in the long run as a result of efficient government projects. If not, he suggests, then it is unfair to single them out to bear the financial burden of these projects. See Michelman, 80 Harv L Rev at 1218-24 (cited in note 8).

146 Of course equal protection doctrine protects certain groups-primarily those defined on the basis of race, gender, and religion - against being singled out for disadvantageous treatment. 
trade agreements, the drug dealer whose car is forfeited, the polluter forced to pay a fine, tobacco companies taxed heavily to support antismoking programs, and any number of other minorities who are "singled out" for financial burdens of various kinds. Unless the compensation requirement for takings is to be expanded essentially to prohibit all government redistribution, a far more elaborate theory would be necessary to cabin off the special category of takings, for which morality or justice requires compensation, from the innumerable uncompensated redistributions routinely effected by government. ${ }^{147}$

For the sake of argument, however, suppose we were given a moral or political theory that somehow successfully justified a compensation requirement limited to a special category of "takings" redistributions. We might nevertheless wonder why fairness should be evaluated at the level of isolated state actions with redistributive consequences rather than at the level of the overall distribution of wealth (or goods more generally) across the relevant population. In other words, we might question why we should be concerned in the takings context about local, transactional justice rather than global, distributive justice. In at least some cases that would count as takings on any recognizable conception, the micro redistributions effected in the transaction between government and plaintiff will actually contribute to a more just macro distribution of wealth. For example, even if on some moral or political theory we would be prepared to acknowledge the local injustice of an uncompensated taking of one person's house to build a public swimming pool for the neighborhood, this tells us nothing about the effect of the transaction on distributive justice. Suppose the condemnee is a wealthy tycoon whose fortune was made on the backs of exploited neighborhood workers. Then, on some plausible theory of distributive justice, the resulting distribution might be globally more just than the status quo ante. ${ }^{1+}$

Of course, not all takings will have perverse distributive justice consequences; but nor is there any reason to expect that compensating takings - that is, transferring wealth from taxpayers to condemnees or

147 Constitutional law attempted a similar project during the Lochner era, when courts struggled to distinguish legitimate exercises of the police power that had redistributive consequences from illegitimate naked wealth transfers. Not surprisingly, the effort foundered intellectually on the difficulty of finding non-arbitrary distinctions between legitimate and illegitimate redistributions. See Cass R. Sunstein, The Partial Constitution 40-67 (Harvard 1993).

148 This example is meant to accommodate both theories of distributive justice that require a specified pattern of holdings to obtain for any given time slice, and dynamic theories of distributive justice, which permit different patterns of holdings to emerge through just processes or institutions. On this distinction, see Robert Nozick, Anarchy, State, and Utopia 153-55 (Basic 1974) (distinguishing "end-result" and "historical" principles of justice); Rawls, $A$ Theory of Justice 83-90 (cited in note 144) (distinguishing "allocative" and "procedural" principles of justice). 
regulatory subjects - will have beneficial distributive consequences. It is certainly easy to imagine a society in which all "takings" were compensated, but the combination of an unjust initial set of entitlements ${ }^{149}$ plus the cumulative effects of all redistributions that did not count as takings resulted in a deeply unjust distributive pattern. Even on a theory which counted every redistribution as a taking, if the initial status quo distribution of entitlements were unjust, then prohibiting redistribution would simply freeze this state of injustice in place..$^{\text {iso }}$ Assuming government is limited to some fixed level of redistribution, then the resources used to accomplish redistributions in takings cases will not be available for redistribution in pursuit of distributive justice. If distributive justice is what counts, then compensating takings may be, if not unjust, at least an impediment to the pursuit of justice. Unless there is some reason why the individual acts of redistribution that get labeled takings are unjust per se, then policing these acts while ignoring broader distributive patterns seems, from the perspective of justice, arbitrary and counterproductive.

One strand of the takings literature purports to offer a reason for why uncompensated takings are intrinsically unjust. Theorists who are committed to the existence of individual property rights argue that these rights, defined in a certain way, are unjustly violated by takings without compensation-irrespective of any broader distributive justice consequences. This seems to be the view of Richard Epstein. Epstein has asserted the existence of a natural right to property - that is, a right that exists independent of custom or positive law-which protects owners' autonomy to possess, use, and dispose of their land and things. ${ }^{\text {s. }}$ On this theory, government violates an individual's property rights whenever it interferes in any way with that person's absolute right to exclude, alienate, or use (at least in any manner that does not amount to a common law nuisance) without providing adequate compensation. ${ }^{\text {s. }}$ Epstein's theory of takings is derived from broader libertarian accounts of justice. On libertarian political theories, whatever pattern of holdings results from just initial acquisitions and just his-

149 See T. Nicolaus Tideman, Takings, Moral Evolution, and Justice, 88 Colum L Rev 1714, 1725 (1988) (pointing out that most private titles to land all over the globe were initially allocated through some combination of force and rent-seeking).

150 See Epstein, Takings at 346-50 (cited in note 59) (struggling with the problem of "past injustices").

151 See id at 3-18. Epstein's view is not entirely clear. He equivocates among natural law, utilitarian, and constitutional justifications for the strong property rights he defends. See Thomas W. Merrill, Rent Seeking and the Compensation Principle, 80 Nw U L Rev 1561, 1562 (1986) (reviewing Epstein's Takings).

152 Epstein, Takings at 58-62 (cited in note 59). There is one major exception. Epstein argues that individual property rights end, and government police powers begin, when one individual inflicts a "nuisance" on another by physically invading her property. Id at 112-25, 229-38. 
torical transactions is itself just, and therefore ought to be protected against government (as well as private) redistribution. ${ }^{133}$ Some argument of this form probably offers the best hope of justifying just compensation for takings, for it promises to identify injustice at the right level of generality - the takings transaction, not the broader distributive pattern that the takings transaction incrementally effects. Whether any libertarian entitlement theory can succeed substantively in justifying just compensation, however, is at best an open question.

Libertarian entitlement theories are quite controversial, and are rejected by those who advocate conceptions of distributive justice concerned to some extent with outcomes or end-states. ${ }^{154}$ While the prolonged and intricate debates between libertarian entitlement theorists and liberal distributive justice theorists cannot be rehearsed in any detail here, the well known philosophical difficulties of libertarian entitlement theories of the sort advocated by Richard Epstein and Robert Nozick may be worth briefly recollecting. ${ }^{1.55}$ Recall that libertarian entitlement theories hold that property rights are justified, and protected against government redistribution, so long as they have been justly acquired. One method of just acquisition is through just transfer-roughly, voluntary exchange, free of force or fraud-from a prior owner who was herself entitled to the property. ${ }^{156}$ But ultimately, back at the beginning of the chain of just transfers, there must be a first owner who managed to acquire just title to the property through some mechanism other than transfer. In order to get off the ground, therefore, entitlement theories need some account of how individuals justly acquire property in the first place. Entitlement theorists have struggled, however, to come up with a principle of just initial acquisition that would explain how morally compelling individual ownership rights with respect to external resources can come into existence. Many libertarian theorists, Nozick and (less clearly) Epstein included, attempt some variation on John Locke's approach to the initial acqui-

153 See Will Kymlicka, Contemporary Political Philosophy: An Introduction 96-98 (Clarendon 1990). The statement in the text is an accurate description of Nozick's libertarian view. See Nozick, Anarchy (cited in note 148). Epstein's view is complicated by his apparent willingness to vest entitlement only in a certain share of the social surplus, in addition to state of nature holdings. See Epstein, Takings at 3-5 (cited in note 59).

154 See, for example, John Rawls, Political Liberalism 267-68 (Columbia 1993); Jeremy Waldron, The Right to Private Property 253-83 (Clarendon 1988).

155 Epstein's theory of takings diverges in important respects from Nozick's views. In particular, Epstein is willing to employ utilitarian arguments and to tolerate forced exchanges by government to a greater extent than is Nozick. See Epstein, Takings at 334-38 (cited in note 59). The basic points in the discussion that follows, however, are sufficiently abstract for these differences to be irrelevant.

156 The idea that entitlements can be transferred from one owner to another while retaining their full moral force is itself hardly free of difficulty. See Waldron, Right to Private Property at 257-62 (cited in note 154). 
sition problem. ${ }^{157}$ They argue that individuals in the state of nature may acquire, through their labor or merely by taking first possession, ownership of natural resources. ${ }^{158}$ Because the fact of first acquisition is not an intuitively obvious moral justification for the establishment of property ownership, entitlement theorists, starting with Locke, have attempted to lend normative credibility to the first possession or first labor principle of acquisition by adding the crucial and seemingly important limitation that acquisition must not leave others worse off ${ }^{159}$ Yet Nozick and Epstein believe that this limitation is at most a trivial impediment to acquisition of property rights, because private property rights and the market economy they support will bring productive efficiency benefits and make virtually everyone better off than she would have been in the state of nature. ${ }^{160}$

Few political theorists, however, are persuaded that this kind of initial acquisition argument is sufficient to justify individual ownership rights. ${ }^{161}$ The argument is generally regarded as inadequate in several respects. Most fundamentally, it is far from obvious how a first-come, first-serve principle of appropriation creates morally significant ownership rights. How can the unilateral actions of one person impose obligations on every other person in the world correlative to the claimed property right $?^{162}$ Nor is it obvious why this principle is morally preferable to alternative ones-for example, that everyone should have an equal chance to appropriate, or the highest-value user gets to appropriate, regardless of who gets there first. ${ }^{163}$ Perhaps universal consent

157 The most relevant aspects of Locke's views on property are presented in John Locke, Two Treatises of Government ch 5 (Cambridge 2d ed 1988) (Peter Laslett ed). For present purposes, it does not matter whether libertarian entitlement theorists such as Nozick and Epstein have correctly understood or applied Locke's views. Leading interpretations of Locke on property include C.B. Macpherson, The Political Theory of Possessive Individualism: Hobbes to Locke (Clarendon 1962); James Tully, A Discourse on Property: John Locke and His Adversaries (Cambridge 1980); Waldron, Right to Private Property at 137-252 (cited in note 154).

158 See Nozick, Anarchy at 174-78 (cited in note 148); Epstein, Takings at 11, 61 (cited in note 59).

159 See Locke, Two Treatises of Government at 288 (cited in note 157) (limiting individual acquisition rights to situations where "there is enough and as good left in common for others"); Nozick, Anarchy at 178 (cited in note 148) (adopting the "Lockean proviso" that individual property rights in an appropriated thing are defeated if "the position of others no longer at liberty to use the thing is thereby worsened"); Epstein, Takings at 10-12 (cited in note 59) (seemingly endorsing the Lockean limitation on acquisitions).

160 See Nozick, Anarchy at 178-82 (cited in note 148); Epstein, Takings at 11 (cited in note 59).

161 For exemplary critiques of these Lockean arguments, see Kymlicka, Contemporary Political Philosophy at 108-18 (cited in note 153); Waldron, Right to Private Property at 262-83 (cited in note 154); G.A. Cohen, Self-Ownership, World-Ownership, and Equality, in Frank S. Lucash, ed, Justice and Equality Here and Now 118-35 (Cornell 1986); G.A. Cohen, Self-Ownership, World Ownership, and Equality: Part II, 3 Social Phil \& Policy 77,77-87 (Spring 1986).

162 See Waldron, Right to Private Property at 266-71 (cited in note 154).

163 See Kymlicka, Contemporary Political Philosophy at 114 (cited in note 153). 
should be required, on the theory that the starting point in the state of nature should be joint ownership rather than no ownership. ${ }^{164}$ Moreover, libertarians such as Nozick and Epstein give us no reason to accept their account of what makes someone "worse off" than she would have been but for someone else's initial acquisition of property. When one person acquires property, surely everyone else in the world is worse off in some respect, if only in that she can no longer use or consume that resource. Even if the private property rights generated through first acquisition contribute to an economic system that leaves most people better off than they would have been in the state of nature (whatever that means), this is hardly sufficient to explain why that initial allocation of property rights should be preferred to an alternative allocation on which at least some of these people would do even better. Presumably there are many systems of property allocation that would produce results preferable to the state-of-nature baseline. Why, then, should we prefer first acquisition to, for example, egalitarian distribution or distribution according to Rawls's difference principle? ${ }^{\text {ts }}$

Even if these difficulties related to the legitimacy of initial acquisitions could be solved, however, libertarian entitlement theories would still be confronted with the most fundamental challenge raised by liberal distributive justice theorists. Libertarians like Nozick and Epstein believe that people are entitled to the fruits of their talents and abilities. If, to use an updated version of Nozick's famous example, Michael Jordan gets extraordinarily rich by selling his unique basketball talents to the many people who will freely pay money to watch him play, then libertarians believe he is entitled to that wealth. ${ }^{166}$ In this view, Jordan is entitled to his natural talents, and has absolute ownership rights over any income derived from just transfers of those talents. Rawlsian liberals question why Jordan, or anyone else, should be entitled to the full benefits of his undeserved talents or circumstances. ${ }^{157}$ Just because Jordan happens to be born with unparalleled athletic ability does not mean he deserves to enjoy unequal rewards from it-not any more than someone born with a physical handicap deserves the worse life prospects that may result. For Rawlsian liberals, government is justified, therefore, in redistributing Jordan's undeserved wealth. More generally, because in this view no one is entitled

164 See Cohen, 3 Social Phil \& Policy at 87-90 (cited in note 161).

165 See Kymlicka, Contemporary Political Philosophy at 114-17 (cited in note 153).

166 See Nozick, Anarchy at 160-62 (cited in note 148) (using the example of Wilt Chamberlain).

167 See Rawls, A Theory of Justice (cited in note 144); Ronald Dworkin, What is Equality? Part 1: Equality of Welfare, 10 Phil \& Pub Aff 185 (1981); Ronald Dworkin, What is Equality? Part 2: Equality of Resources, 10 Phil \& Pub Aff 283 (1981). 
to wealth that accumulates as a result of undeserved natural abilities or undeserved advantages in the processes of initial acquisition, transfer, or productive use of property, redistribution is often entirely justifiable and indeed morally necessary to compensate those who suffer from undeserved disadvantages in natural abilities or in these processes of acquisition, exchange, and production.

But perhaps theoretical criticisms such as these-and potential libertarian responses-are largely beside the point for purposes of evaluating the moral or political necessity of just compensation for real-life takings. After all, even if we were to endorse a libertarian entitlement account of justice, we should not lose sight of the fact that virtually all real-life property can be traced back to what must be, on any theory, unjust acts of initial acquisition or unjust transfers-for example, forcible appropriations by conquest. Consequently, entitlement theories cannot justify the protection of existing property claims. ${ }^{1.3}$ Unless society decides to engage in a grand redistribution to rectify past injustices and recreate the hypothetical results of an historical pattern of just acquisitions and just transfers of property rights, entitlement theories will have little to say about the justice of real-life government redistributions. And even if this were somehow to take place, it is not clear that libertarian entitlement theories could be made to yield results at a practical level of generality. For example, in order to know what types of uncompensated redistribution were permitted, we would need to know the scope of property rights. Epstein, as we have seen, defines property rights to include absolute freedom of possession, use, and disposition, except where use would effect a common law nuisance. ${ }^{169}$ But this is just by morally arbitrary reference to Blackstone and the common law. ${ }^{100}$ What, then, is to prevent us from conceding absolute property rights to libertarian entitlement theorists, while narrowly circumscribing the scope of what counts as property? For example, in accordance with the classical liberal understanding, we could forbid only uncompensated physical dispossessions of real estate. ${ }^{171}$ Moreover, a libertarian entitlement theory that specifies prop-

168 Both Nozick and Epstein concede that the status quo distribution of property is unjust. See Nozick, Anarchy at 152-53 (cited in note 148); Epstein, Takings at 346 (cited in note 59). See also Tideman, 88 Colum L Rev at 1725 (cited in note 149). Nozick admits the need for some system of rectification to recreate the pattern of distribution that would have resulted but for injustices in acquisition and transfer before it is possible to use his entitlement theory to criticize redistribution. See Nozick, Anarchy at 152-53,230-31 (cited in note 148). Epstein's solution to this problem is less clear. See Epstein, Takings at 346-50 (cited in note 59).

169 See Epstein, Takings at 58-62 (cited in note 59).

170 See Margaret Jane Radin, The Liberal Conception of Property: Cross Currents in the Jurisprudence of Takings, 88 Colum L Rev 1667, 1670 (1988); Mark Kelman, Taking Takings Seriously: An Essay for Centrists, 74 Cal L Rev 1829, 1833-36 (1986); Jeremy Paul, The Hidden Structure of Takings Law, 64 S Cal L Rev 1393, 1416-23 (1991).

171 See Thomas C. Grey, The Disintegration of Property, in J. Roland Pennock and John W. 
erty rights does not necessarily tell us anything about how these rights must be enforced. Perhaps property rights have only moral force, or perhaps violations of property rights should be punished by criminal sanctions. There is nothing incoherent about the existence of absolute property rights in the absence of just compensation for violations.

Finally, bracketing all of the difficulties just surveyed, we should also keep in mind how radical of a challenge entitlement theories present to the contemporary jurisprudence of constitutional property. Post-Realist jurisprudence conceptualizes property as a positive, government-created entitlement. ${ }^{12}$ In this view, any approach to takings that starts with "some natural and unique set of entitlements that are protected under a system of private property" ${ }^{\text {"173 }}$ will simply be a nonstarter. ${ }^{174}$ Rather than envisioning a core set of rights essential to ownership of property, modern scholars see bundles of rights with respect to things that can be infinitely disaggregated by positive law into various divisions of entitlement. ${ }^{175}$ At any given time government regulates some uses of property and creates certain patterns of entitlements, but there is nothing sacred about the status quo. In other words, there is no such thing as a taking of private property; there are merely redefinitions of property rights. The fundamental normative challenge of takings law and jurisprudence, in the modern view, is to explain when and why government is obligated to compensate owners for reducing their stock of property entitlements given that these owners had no pre-political claim to the entitlements in the first place. ${ }^{176}$ Such an explanation, it is generally understood, will require reference to the values and purposes private property does and should serve, and to norms of legitimate government behavior. ${ }^{17}$ Moral arguments that start by identifying pre-legal property rights simply do not address these questions and, therefore, will strike most courts and legal scholars as hopelessly anachronistic. Because property ownership is not re-

Chapman, eds, Nomos XXII: Property 73-74 (NYU 1980).

172 See Bruce A. Ackerman, Private Property and the Constitution 26-31 (Yale 1977).

173 Epstein, Takings at 230-31 (cited in note 59). See also id at 5 ("[A]ll theories of natural rights reject the idea that private property and personal liberty are solely creations of the state.").

174 See, for example, C. Edwin Baker, Property and Its Relation to Constitutionally Protected Liberty, 134 U Pa L Rev 741, 743 (1986) ("I will here assume what I think should be obvious: that the notion of a complete set of timeless, natural, or proper property rules is absurd.").

175 See Thomas C. Grey, The Malthusian Constitution, 41 U Miami L Rev 21, 30-31 (1986); Joseph L. Sax, Takings and the Police Power, 74 Yale L J 36, 61 (1964); Thomas C. Grey, The Disintegration of Property at 69 (cited in note 171).

176 See Grey, 41 U Miami L Rev at 30-31 (cited in note 175); Tribe, American Constitutional Law at 607-13 (cited in note 143).

177 See Grey, $41 \mathrm{U}$ Miami L Rev at 27 (cited in note 175); Tribe, American Constitutional Law at 608-09 (cited in note 143). To point out the conventionally expressed need for such an account is not, of course, to renounce skepticism as to whether a convincing account is possible. 
garded as an all-or-nothing proposition-in scope or in time-it is difficult to think about the injustice of uncompensated takings in terms of depriving individuals of absolute ownership of something.

Of course none of this amounts to proof that compensation could never be adequately justified by a libertarian entitlement theory or by some other theory grounded in morality or justice. ${ }^{178}$ The ambition of this Part is merely to refute complacent assertions of the unfairness or injustice of uncompensated takings. As the foregoing discussion hopefully illustrates, the issue of compensation for takings, as a matter of moral or political theory, is far more difficult than is usually recognized, and any minimally adequate defense of just compensation in these terms will rest on deeply controversial premises.

\section{B. Constitutional Torts}

This Part asks whether there is a persuasive non-deterrence rationale for forcing government to pay compensation to the victims of constitutional torts. In justifying constitutional tort damages, courts and commentators emphasize both the benefits of cost-internalization in deterring government from committing constitutional violations and the intrinsic desirability of compensating victims. ${ }^{179}$ With the deterrence rationale out of play, however, the supposed benefits of compensating victims must bear the entire justificatory burden. Unfortunately, academic and judicial discussions of constitutional torts seldom bother to articulate reasons why compensating victims might be desirable. ${ }^{180}$ We can speculate, though, that such reasons will be found, if at all, in the domain of morality or justice. ${ }^{181}$

Before addressing the moral dimensions of the compensation issue, however, we should pause to notice the possibility-heretofore unremarked in the literature-that a compensation requirement for constitutional torts will have predictably perverse allocative efficiency consequences. The basic argument is that insurance theory, as introduced in the takings context, actually cuts against the payment of compensation for (at least some types of) harms caused by constitutional torts. The general form of the insurance argument is familiar

178 Other libertarian theories, for example, pursue somewhat different strategies and are problematic in different ways than Nozick's or Epstein's. See, for example, David P. Gauthier, Morals By Agreement (Oxford 1986); Brian Barry, Theories of Justice 249-54, 388-92 (California 1989) (criticizing Gauthier's contractarian theory of libertarianism).

179 See, for example, Jeffries, 75 Va L Rev at 1461-64 (cited in note 14).

180 For a notable exception, see John C. Jeffries, Jr., Compensation for Constitutional Torts: Reflections on the Significance of Fault, 88 Mich L Rev 82, 90-96 (1989) (exploring possible rationales for compensation).

181 See Owen $v$ City of Independence, 445 US 622, 651 (1980) (noting the "injustice" of allowing the victims of constitutional violations to go without compensation). 
from the economic literature on pain and suffering damages in tort. ${ }^{182}$ The argument, in that context, goes as follows. For certain categories of tort claims, most clearly those based on products liability, the tort system functions as a form of compulsory insurance. ${ }^{183}$ Consumers pay premiums to manufacturers, in the form of higher prices for their products, in exchange for indemnification from manufacturers for injuries caused by these products. Is this insurance that consumers would choose to buy in a free market? In general, people purchase insurance because of risk aversion, which in turn is (at least partially) a product of the diminishing marginal utility of money. ${ }^{184}$ Because the utility of a person's first dollar is greater than the utility of her last dollar, she will be willing to trade some of her last-earned dollars for some of her first-earned dollars. Insurance enables her to do so by paying last-earned dollar premiums in exchange for indemnification against expected losses of first-earned dollars. Many people willingly pay for health insurance, for instance, because the dollars they spend now on premiums would bring them relatively little utility if spent on luxury goods, whereas the same number of (expected) dollars which they would recover from their insurance companies in the event of an illness would buy greater utility when used for medical treatment. ${ }^{185} \mathrm{~A}$ utility-maximizing individual will continue to buy insurance, transferring wealth from her pre-accident state to her post-accident state, until the value of the marginal dollar of insurance premiums equals the expected value of the insurance coverage purchased by that dollar. For insurance through the tort system to be efficient, then, damage awards for tort losses should equal the amount of first-party insurance that consumers would choose to purchase in an efficient private marketthat is, the amount at which consumers would be indifferent between pre-loss and post-loss dollars. ${ }^{186}$

182 See, for example, Steven P. Croley and Jon D. Hanson, The Nonpecuniary Costs of Accidents: Pain-and-Suffering Damages in Tort Law, 108 Harv L Rev 1785 (1995); Robert Cooter, Towards a Market in Unmatured Tort Claims, 75 Va L Rev 383 (1989); Alan Schwartz, Proposals for Products Liability Reform: A Theoretical Synthesis, 97 Yale L J 353,362-67 (1988); George L. Priest, The Current Insurance Crisis and Modern Tort Law, 96 Yale L J 1521 (1987).

183 Note that any category of tort claims where there is a price nexus between tortfeasors and tort victims would be fair game for the straightforward insurance argument summarized here. The argument could be extended to the rest of tort law, but only by introducing interpersonal utility comparisons.

184 See Kenneth S. Abraham, Distributing Risk: Insurance, Legal Theory, and Public Policy 11-12,24 (Yale 1986).

185 See Croley and Hanson, 108 Harv L Rev at 1793-97 (cited in note 182).

186 Commentators debate whether the absence of a full-fledged private market in first-party pain and suffering insurance proves that consumers do not demand it, or instead only that consumers do not demand it in addition to the tort system, or that consumers would, in fact, buy insurance if supply-side market failures did not prevent it from being offered. See id at 1845-95 (pointing out the real-life existence of pain and suffering insurance in certain isolated contexts and arguing that its absence elsewhere is attributable to factors other than absence of demand; 
Insurance theorists argue that the tort system forces consumers to buy insurance that they would not choose to purchase in an efficient private market, and therefore decreases their welfare by forcing them to transfer money from higher- to lower-valued states. ${ }^{157}$ Consumers demand insurance, the argument goes, only against losses that reduce their wealth-either directly, by destroying property or reducing income flow, or indirectly, by creating the need for various kinds of expenditures, such as medical care. This is because reductions in wealth increase the marginal utility of money. Losses that do not reduce wealth, in contrast, do not increase the marginal utility of money. ${ }^{18 s}$ For example, a professor who loses his left foot in an accident, once medical costs are paid for, will not necessarily place a higher value on post-injury than pre-injury dollars. Indeed, if his greatest joy is snow skiing, he may place a higher value on pre-injury dollars, which can buy him the pleasure of skiing, than on post-injury dollars, which will be spent on less enjoyable and cheaper substitute leisure activities, such as movies. ${ }^{199}$ Consumers would not demand insurance against losses that would not increase their marginal utility of income. Because pain and suffering as a result of an accident does not directly reduce wealth, and because it seems as likely to decrease the consumption value of income as to increase it, the argument goes, consumers would not choose to purchase insurance coverage for this general category of losses. Consequently, the tort system may reduce the welfare of consumers by forcing them to buy insurance against pain and suffering that reduces their overall utility.

The same argument applies to compensation for constitutional torts. ${ }^{190}$ In exchange for "premiums" in the form of taxes, government indemnifies citizens against harms caused by violations of their constitutional rights. ${ }^{191}$ Under current Supreme Court doctrine, constitu-

also summarizing the opposing literature). 1987).

187 See, for example, Steven Shavell, Economic Analysis of Accident Law 230-31 (Harvard

188 See id at 228-31.

189 For risks such as this, which decrease the value of money, consumers will actually demand disinsurance to enable them to transfer wealth from their post- to pre-loss states. See Croley and Hanson, 108 Harv L Rev at 1800-01 n 47 (cited in note 182) (citing sources). On the other hand, if the professor in this example substituted a more expensive leisure activity, such as collecting rare automobiles, to achieve the same utility as pre-accident skiing had provided, the accident would increase the value of money, and the professor would benefit from insurance.

190 How damning a criticism this is depends, of course, on the truth of the insurance argument. The dominant view among economic commentators is that pain and suffering damages in private law tort are incompatible with consumers' insurance preferences. But this view has been subject to recent criticism. See Croley and Hanson, 108 Harv L Rev at 1791 (cited in note 182) (acknowledging the conventional wisdom of the insurance argument and proceeding to attack it along a number of dimensions).

191 One disanalogy between constitutional torts and insurance is that tax premiums are not risk-rated, so classes of individuals more likely to suffer harms from constitutional violations will 
tional tort plaintiffs may recover for monetary losses and intangible harms resulting from constitutional violations, including reputational injuries and emotional distress. ${ }^{1.2}$ Insurance theory teaches that most plaintiffs would be willing to buy insurance against monetary losses, but not against intangible dignitary or emotional harms that have no positive effect on the post-violation value of money.

Yet these types of intangible harms must account for a large portion of constitutional tort damages. Here are some typical constitutional tort cases: the government violates free speech rights by breaking up a peaceful political demonstration or denying a parade permit based on the content of speech; police officers violate the Fourth Amendment by searching the house of an innocent person without a warrant, or arresting and briefly detaining someone without probable cause; a public employer violates the procedural due process rights of an employee by failing to provide notice or an adequate hearing before his (justifiable) termination; a public university discriminates against students on the basis of race or gender. None of these cases generates any negatively wealth-impacting damages. The constitutional violations cause no medical expenses, property damage, or lost wages, and therefore recovery in each case would be limited to emotional distress and reputational harms. Because the victims' marginal utility of money does not increase in the post-injury state, they would not choose to pay higher taxes in the pre-injury state in exchange for indemnification. Requiring them to do so through the constitutional tort system reduces their welfare.

Other types of constitutional torts do reduce the wealth of the victims and increase the post-violation marginal utility of money. Unconstitutionally excessive force by the police that results in medical expenses or retaliatory public employment discharges that result in lost wages, for example, generate actual monetary losses. For these wealth-reducing harms, insurance theory suggests that tax-financed constitutional tort damages could increase welfare. ${ }^{193}$ The point re-

not pay higher taxes for their greater insurance benefits. In fact, lower-income people, who pay less in taxes, may be disproportionately victims of constitutional violations because they interact more often with the police, public school administrators and teachers, welfare workers, and the like. If so, then insurance through the constitutional tort system, whatever its effects on allocative efficiency, will have predictable, and perhaps even desirable, distributive consequences. For this argument to support constitutional tort damages, such damages would have to compare favorably to other redistributive mechanisms, such as tax and transfer. This seems doubtful.

192 See text accompanying note 78 .

193 Still, it is an important further question whether the government is the most efficient provider of insurance against constitutional violations. The private market might be superior. See text accompanying notes 136-40 (discussing Kaplow's argument that private insurance would be more efficient than government compensation in the takings context). Also, individuals who already pay for first-party health and property insurance would not demand duplicative coverage through the constitutional tort system even for wealth-reducing harms. 
mains, however, that for what is probably the bulk of compensable constitutional harms, mandatory insurance reduces the welfare of taxpayer-beneficiaries. If efficiency cuts in any direction in the context of constitutional torts, therefore, it is probably against paying compensation.

Setting efficiency aside, let us now consider potential noninstrumental defenses of a compensation requirement grounded in moral or political philosophy. At the outset, we can easily dismiss any argument from distributive justice for the same reasons as in the takings context. Constitutional violations generally reduce the welfare of victims, but this predictable change in welfare tells us nothing about the total welfare of the victim class - the more relevant concern from the perspective of distributive justice. Just because an advertising restriction violates the free speech rights of a corporation, or a summary tenure denial violates the procedural due process rights of a public law school professor, for example, does not mean that the corporation (or its shareholders) or the professor can stake a just claim to a government wealth transfer. Surely there are many others whose constitutional rights have not been violated, but who nonetheless have stronger claims to a greater share of social wealth. ${ }^{194}$ Indeed, the victims of some types of constitutional rights will be systematically less sympathetic distributive justice claimants. Fourth Amendment privacy rights, for example, are disproportionately enjoyed by those who live their lives in detached, private homes, private cars, and private offices - that is, by the relatively wealthy. ${ }^{195}$ First Amendment free speech rights similarly offer greater benefit to those who can afford access to the media or contributions to political campaigns. A theory of distributive justice that would entitle the fortunate beneficiaries of privacy and speech rights to demand that less-well-off taxpayers subsidize the maintenance of their greater wealth by indemnifying them against violations of these rights would certainly be counterintuitive. Even if the particular losses resulting from a constitutional violation were somehow significant under one's preferred theory-perhaps because it might serve as a (highly imperfect) proxy for net total welfare-it is hard to imagine why, on any plausible theory of distributive justice, the victims of constitutional violations would be singled out as uniquely entitled to government wealth transfers. What about the countless others who suffer more severe losses as a result of other types of undeserved contingencies, whether caused by government or not-for example, perfectly constitutional changes in the tax code or in welfare laws, eco-

194 See Stephen R. Perry, On the Relationship between Corrective and Distributive Justice, in Jeremy Horder, ed, Oxford Essays in Jurisprudence: Fourth Series 12-13 (Oxford 2000).

195 See William J. Stuntz, The Distribution of Fourth Amendment Privacy (forthcoming in the Geo Wash L Rev). 
nomic recessions, illnesses, or hurricanes $?^{116}$ In sum, because distributive justice is concerned with the global distribution of wealth or other goods, no theory of distributive justice will be sufficiently localized to justify compensation for particular harm-causing transactions, whether takings or constitutional torts.

The strongest noninstrumental case for compensating constitutional torts is based not on distributive justice, but on corrective justice. ${ }^{197}$ Aristotle distinguished justice in distribution, which is concerned with the distribution of wealth, honors, and other goods according to individual worth or merit, ${ }^{198}$ from justice in rectification, which is narrowly concerned with particular transactions between or among individuals. ${ }^{199}$ For Aristotle, justice in rectification requires that, when one person profits from an injustice that causes harm to another, the wrongdoer must be made to give over the unjust profit to the victim, thereby restoring equality. But "equality" with respect to justice in rectification, in contrast to justice in distribution, is defined strictly as the status quo at the time of the particular injustice. As Aristotle explains, it is of no consequence to justice in rectification that the victim happens to be possessed of vast, distributively unjust wealth or that the particular transaction effects a transfer that counts as an improvement from the perspective of distributive justice. ${ }^{200}$ Modern theorists of tort law have invoked justice in rectification-or, as it is more commonly called, "corrective justice"-as a noninstrumental justification for compensating wrongful private harms. ${ }^{201}$ Corrective justice theorists differ on many points, but the least common denominator of their views is that the duty to rectify or compensate is triggered when one person wrongfully causes harm to, or benefits at the expense of, another. By distinguishing losses caused by "wrongdoing" from other

196 See Jeffries, 88 Mich L Rev at 90-92 (cited in note 180) (arguing that "the mere fact that injury is caused by government unconstitutionality is not, in itself, a suitable test" for who should receive damages).

197 See id at 93.

198 Aristotle, Nicomachean Ethics 1131a10-1131b25 (Hackett 1985) (Terence Irwin, trans).

199 Id at 1131 b25-1132b20.

200 Aristotle states:

For here it does not matter if a decent person has taken from a base person, or a base person from a decent person. ... Rather, the law looks only at differences in the harm [inflicted], and treats the people involved as equals, when one does injustice while the other suffers it, and one has done the harm while the other has suffered it. Hence the judge tries to restore this unjust situation to equality, since it is unequal.

Id at $1132 \mathrm{a}$.

201 See, for example, Emest J. Weinrib, Causation and Wrongdoing, 63 Chi Kent L Rev 407 (1987); Jules Coleman, Corrective Justice and Wrongful Gain, 11 J Legal Stud 421 (1982); Richard A. Posner, The Concept of Corrective Justice in Recent Theories of Tort Law, $10 \mathrm{~J}$ Legal Stud 187 (1981); Richard A. Epstein, Nuisance Law: Corrective Justice and its Utilitarian Constraints, $8 \mathrm{~J}$ Legal Stud 49 (1979). 
losses, and by bracketing the background distribution and focusing solely on the bilateral interaction between wrongdoer and victim, corrective justice theories potentially offer a justification for transferring wealth based solely on the fact of a constitutional violation.

Accepting, for a moment, the importance of transactional rectification as a moral principle, we might nevertheless question how well corrective justice theories, which have been developed in the legal literature primarily in the context of common law torts, translate into the somewhat different realm of constitutional remedies. For one thing, it is not clear whether a collective entity like the government can qualify as a moral agent for purposes of corrective justice. ${ }^{202}$ This concern applies most directly to suits against local governments, since damages claims based on constitutional violations by state governments must take the form of suits against officers in their individual capacities..$^{203}$ Even with respect to state violations, though, the formality of pleading against an individual officer should not disguise the fact that constitutional "wrongdoing" is often best understood as an institutional, not individual, phenomenon. ${ }^{204}$ Singling out the government official closest to the harm as the constitutional "wrongdoer" will be arbitrary from a moral point of view if that officer is merely responding to bureaucratic incentives or carrying through the inevitable results of lack of training or resources.

Recognizing that constitutional tort compensation ultimately comes from the pockets of taxpayers further attenuates the connection between moral responsibility and the burden of rectification. Corrective justice theories ground the duty to rectify in the causation of wrongful harms. But taxpayers do not "cause" constitutional violations in any intuitive sense of causation, nor are they morally responsible for constitutional wrongdoing. (Although some taxpayers will in-

202 See Catharine Pierce Wells, Corrective Justice and Corporate Tort Liability, $69 \mathrm{~S}$ Cal L Rev 1769,1775-76 (1996) (pointing out the difficulty of justifying corporate tort liability in terms of corrective justice).

203 State governments and officers acting in their official capacity are protected against Section 1983 damages by the Eleventh Amendment. See Quern v Jordan, 440 US 332, 338-45 (1979). Local governments are subject to liability for constitutional violations pursuant to an official "policy or custom." See Monell v Department of Social Services of the City of New York, 436 US 658,694 (1978).

204 See Christina B. Whitman, Government Responsibility for Constitutional Torts, 85 Mich L Rev 225 (1986). See also Barbara E. Armacost, Qualified Immunity: Ignorance Excused, 51 Vand L Rev 583, 670 (1998) ("Were constitutional damages liability, with its implication of fault and blameworthiness, to attach in the first instance to the governmental body rather than to an individual, the meaning and power of the designation 'wrongdoer' would be significantly reduced.").

205 See Schuck, Suing Government at 101 (cited in note 14) ("Imposing liability upon individual officials, whose 'objective bad faith' may consist of little more than being an instrument of bureaucratic, political, and social processes over which they have little or no effective control, cruelly mocks [the moral basis of public law]."). 
evitably be included among the class of persons who benefit from the constitutional violation, this cannot be a sufficient basis for placing the burden of rectification on taxpayers generally.) Only a quite imaginative theory of corrective justice could accommodate the absence of correlativity between, on the one hand, wrongdoing and causation and, on the other, the nominal or actual burden of rectification.

On the other side of the corrective justice equation, identifying an individual victim entitled to rectification would also seem highly problematic for many types of constitutional violations. When the government violates the First Amendment by regulating indecent material on the internet, ${ }^{206}$ for example, is the proper corrective justice claimant the internet service provider, the owner of the web site posting the banned content, the potential viewers of that content, or every citizen who would otherwise have benefited from a more robust marketplace of ideas? Analogous questions arise with respect to violations of other "systemic" constitutional rights, ones that prohibit government actions for reasons having nothing to do with preventing specified forms of harms to identifiable individuals. ${ }^{207}$ Whatever the point of prohibiting the racial gerrymandering of electoral districts, ${ }^{228}$ prayer in school, ${ }^{2, s}$ warrantless searches, ${ }^{210}$ or race-based affirmative action, ${ }^{211}$ preventing immediate harm to some specified individual is not it. ${ }^{212}$ Individual plaintiffs may be entitled to recover monetary damages in constitutional tort cases for harms stemming from these types of violations, but it would be entirely artificial to pretend that these individuals were the only victims or that their harms, while perhaps more tangible or immediate, were especially important or unjust from a moral point of view. ${ }^{213}$ In contrast to private torts, where corrective justice theorists have had little problem identifying an individual "victim" who has been wrongly deprived of some entitlement such as property or bodily integrity, the "wrongdoing" of many types of constitutional violations simply does not inhere in the deprivation of anything analogous to an individual entitlement.

206 See Reno $v$ ACLU, 521 US 844 (1997).

207 See Jeffries, $75 \mathrm{Va} \mathrm{L} \mathrm{Rev} \mathrm{at} 1471$ (cited in note 14).

208 See Miller $v$ Johnson, 515 US 900 (1995); Shaw $v$ Reno, 509 US 630 (1993).

209 See Wallace v Jaffree, 472 US 38 (1985); Abington Township School District v Schempp, 374 US 203 (1963); Engel $v$ Vitale, 370 US 421 (1962).

210 See Mapp v Ohio, 367 US 643 (1961).

211 See Adarand Constructors, Inc v Pena, 515 US 200 (1995).

212 For more fully developed theoretical explanations of why many constitutional rights cannot be understood as individual entitlements, see Pildes, $27 \mathrm{~J}$ Legal Stud at 725 (cited in note 81); Raz, Ethics in the Public Domain at 29-44 (cited in note 80).

213 The rules of standing in constitutional adjudication gaudily display this artificiality precisely because they require plaintiffs to manufacture individualized harms in order to challenge government action that is constitutionally objectionable for other, more systemic reasons. See Pildes, $27 \mathrm{~J}$ Legal Stud at 732-33 (cited in note 81). 
Aside from the issues of who is the morally relevant payer of rectification or victim-recipient of rectification in the constitutional setting, we might question whether monetary damages could possibly serve as a morally appropriate form of rectification. Recall that the insurance theory critique was driven by the insight that many types of constitutional harms - even setting aside whatever harm inheres in the very fact of the violation -involve dignitary and emotional losses that do not translate in any straightforward way into wealth effects. ${ }^{214}$ This suggests the possibility that constitutional harms and dollars are incommensurable, meaning that they cannot be compared on a single metric, or ranked on a single scale of value. ${ }^{215}$ Incommensurability between type of harm and currency of repair would seem to present a challenge to any theory of corrective justice. ${ }^{216}$ If the money received by the victim cannot meaningfully replace what she lost or restore her to the pre-violation, rightful position, we might wonder how monetary damages can achieve rectification in any morally significant sense. ${ }^{217}$

To further complicate matters, the mismatch between compensatory damages and constitutional wrongdoing is not just qualitative, but quantitative as well. Corrective justice possesses the greatest intuitive appeal where the wrongful gains and losses are proportional, paradigmatically where the wrongdoer appropriates property from the victim and then is made to return it (or to disgorge something of determinately equivalent value). ${ }^{218}$ Under the current system of constitutional tort damages, however, the relationship between wrongful gains and losses is seldom proportional and often entirely arbitrary. Consider two cases of free speech violations. ${ }^{219}$ In the first case, government enforces an ordinance prohibiting "live entertainment" against

214 See text accompanying notes 187-93.

215 See Cass R. Sunstein, Incommensurability and Valuation in Law, 92 Mich L Rev 779 (1994); Elizabeth Anderson, Value in Ethics and Economics 55-59 (Harvard 1993); Joseph Raz, The Morality of Freedom 321-66 (Clarendon 1986).

216 See Margaret Jane Radin, Compensation and Commensurability, 43 Duke L J 56 (1993) (exploring the tension between corrective justice understandings of personal injury in tort and the problem of incommensurability between monetary damages and bodily integrity).

217 See id. After recognizing the challenge of incommensurability to corrective justice rationales for compensating nonpecuniary harms in tort, Radin argues that compensation may nevertheless "symbolize public respect for rights and public recognition of the transgressor's fault by requiring something important to be given up on one side and received on the other, even if there is no equivalence of value possible." Id at 69 . Radin concedes, however, that only a theory of corrective justice that abandoned the goal of rectification could be satisfied by compensation thus understood. Id at 68.

218 See Jason W. Neyers, The Inconsistencies of Aristotle's Theory of Corrective Justice, 11 Canadian J L \& Juris 311, 320-27 (1998) (describing Aristotle's view of correlative gain and loss); Stephen R. Perry, The Moral Foundations of Tort Law, 77 Iowa L Rev 449, 457-61 (1992) (discussing the relationship between reparation of loss and disgorgement of gain in corrective justice theories); Coleman, $11 \mathrm{~J}$ Legal Stud at 424-25 (cited in note 201).

219 This example is borrowed from Jeffries, 75 Va L Rev at 1481-84 (cited in note 14). 
an adult entertainment establishment featuring nude dancing, forcing it out of business. In the second, the government breaks up a peaceful political demonstration in order to squelch criticisms of the current administration. On most understandings of the values protected by the First Amendment, the "wrongdoing" inflicted by the second violation far exceeds that inflicted by the first. ${ }^{200}$ To the extent that the wrongfulness of the government's activity in the two cases correlates with its (or society's) wrongful gains, corrective justice may require proportionality of compensation. Yet the plaintiff in the first case could be entitled to substantial constitutional tort damages, compensating him for the financial loss of his business. The plaintiffs in the second case, in contrast, would be hard pressed to prove any substantial injuriesat best, they might collect some money for dignitary or emotional harms. Because the losses suffered by the individual victims in these cases are merely coincidental to the constitutional harms inflicted on society as a whole, and correspondingly coincidental to the government's (or, again, society's) wrongful gain, there is no morally significant relationship between the constitutional wrongdoing and the level of monetary damages. Conceivably, the disproportionality problem might be solved by scaling compensation to the intrinsic wrongfulness of the constitutional harm or to the government's or society's wrongful gains. But this seems impossible in practice (if not in theory), and in any case, it would only exacerbate the incommensurability problem.

The discussion so far has taken for granted the significance of transactional rectification as a normative principle. But this assumption is hardly necessary. Even if corrective justice definitively required compensation for constitutional torts - which, as the preceding discussion demonstrates, is by no means clear-justice at the transactional level might well be rejected or downplayed by the designers of a just system of constitutional law and remedies. As in the takings context, ${ }^{21}$ principles of distributive justice may be of greater relevance and importance. After all, if the net effect of a system of corrective justice is to protect and entrench a deeply unjust status quo distribution of holdings, it is tempting to think that we could do without that type of "justice." Based on reasoning along these lines, the intuitive priority

220 Protecting political expression against government crackdowns is often understood to be the core purpose of the free speech right. See Lillian R. BeVier, The First Amendment and Political Speech: An Inquiry Into the Substance and Limits of Principle, 30 Stan L Rev 299, 30708 (1978); Alexander Meiklejohn, The First Amendment is an Absolute, $1961 \mathrm{~S} \mathrm{Ct}$ Rev 245, 25557.

221 See text accompanying notes 152-54.

222 See Jules L. Coleman, Risks and Wrangs 351 (Cambridge 1992) (highlighting the weakness of corrective justice). See also Larry A. Alexander, Causation and Corrective Justice: Does Tort Law Make Sense?, 6 L \& Phil 1 (1987) (describing the conflict between distributive and corrective justice and arguing that corrective justice should be discarded). 
of distributive justice has always bedeviled corrective justice theorists. And it presents an especially compelling challenge to the significance of transactional rectification in the constitutional torts setting, where the government bears responsibility both for transactional wrongdoing and for wealth redistribution in pursuit of distributive justice. Compensating constitutional torts cannot be expected to bring society closer to any just distributive pattern and will, in many cases, exacerbate the injustice of the existing distribution by channeling wealth collected from taxpayers to plaintiffs who are less deserving beneficiaries of wealth transfers. Additionally, the transaction costs of administering corrective justice in practice could be used to buy greater distributive justice by funding the institutions necessary to effect redistribution. Achieving corrective justice, therefore, will always entail some sacrifice of distributive justice.

The only way to make the conflict between distributive and corrective justice disappear is to reduce the latter to the former. For example, a theory of corrective justice might define wrongful transactions as ones that cause departures from a just distribution. But that move comes at the cost of denying to corrective justice any independent normative force. ${ }^{23}$ So long as corrective justice is not just ancillary to distributive justice, its normative force will depend on some morally compelling reason for protecting the status quo as between two parties irrespective of the distributive justice of their holdings. ${ }^{24}$ Correc-

223 See Perry, Corrective and Distributive Justice (cited in note 194). This point warrants some elaboration. Certainly, if transactional wrongdoings were defined as departures from a just distribution, then corrective and distributive justice could be made compatible. But on this definition, corrective justice could not underwrite compensation based merely on the fact of a constitutional tort; instead, compensation would be justified only if the constitutional tort shifted the overall pattern of distribution of wealth or other goods in society away from the perfectly just distribution and a transfer payment from government (taxpayers) to victim would restore a more just pattern. Once that is conceded, however, we are no longer talking about "compensation" for particular wrongs or harms, but only of legitimate claims to government redistribution that have no special connection to the constitutional tort transaction. Hurricane victims might be entitled to government compensation for exactly the same reason, yet we would not want to say they have a claim grounded in corrective justice. See Peter Benson, The Basis of Corrective Justice and Its Relation to Distributive Justice, 77 Iowa L Rev 515, 529-32 (1992). Along similar lines, we might reconcile corrective and distributive justice by supposing that corrective justice only becomes relevant once a just distributive scheme is already in place and requires compensation only where the transfer payment would offset departures from this distribution. See Rawls, $A$ Theory of Justice at 10-11 (cited in note 144) (seemingly taking this view of corrective justice). But then corrective justice is simply reduced to an instrumental mechanism for protecting distributive justice - and a quite irrelevant mechanism in the real world, where the existing distribution is far from just. Finally, note that this discussion ignores what is perhaps the most difficult problem faced by a view of corrective justice as ancillary to distributive justice, which is how corrective justice could preserve a just distribution on a dynamic theory of distributive justice, where there is no determinately just distributive pattern for any given time slice. See Perry, Corrective and Distributive Justice at $16-17$.

224 See Ernest J. Weinrib, The Idea of Private Law 76-80 (Harvard 1995); Coleman, Risks and Wrongs at 350-54 (cited in note 222); Perry, 77 Iowa L Rev at 451-52 (cited in note 218). 
tive justice theorists have suggested a number of often conflicting and always abstruse candidates for such reasons, including realization of "the free purposiveness of self-determining activity" as elaborated by Kant; ${ }^{25}$ protection of local coordination norms that contribute to "rational social stability"; ${ }^{266}$ vindication of a general concern with "human well-being" localized by the moral consequences of "outcomeresponsibility"; ${ }^{27}$ and the preservation of entitlements that represent Hegelian exercises of willful control. ${ }^{228}$ No matter what moral principle drives one's preferred theory of transactional justice, however, it must be weighed against the (rather more straightforward) value of distributive justice.

The criteria for balancing corrective and distributive justice must, of course, come from somewhere outside of the theory of corrective justice itself, and perhaps from outside of any theory of justice. ${ }^{29}$ This may explain why corrective justice theorists tend not to concentrate on the issue of how to make the trade-off. A number of leading theorists have, however, suggested one strategy for accommodating corrective and distributive justice-and it is a strategy that would seem to exclude compensation for constitutional torts from the corrective sphere. Ernest Weinrib, Jules Coleman, and Ronald Dworkin each have suggested an institutional and jurisprudential division of labor between the two types of justice, with distributive justice primarily relevant to the political process and public law, and corrective justice primarily relevant to judicial resolution of private law disputes. ${ }^{230}$ While distributive justice permits or obligates government to redistribute entitlements and suspends corrective constraints on government redistributions in pursuit of distributive justice, the suggestion goes, corrective justice forbids private parties from effecting similar redistributions. Coleman, Dworkin, and Weinrib offer somewhat different reasons in support of this idea, but for present purposes we can simply note that insofar as corrective justice must be limited to interactions between private parties, it cannot be used to justify compensating the victims of constitutional torts. Here is yet another reason why corrective justice theories developed in the private law context may not extend to constitutional torts.

Of course other approaches to reconciling corrective and distributive justice are possible, but the point remains that, in order to

\footnotetext{
225 Weinrib, The Idea of Private Law at 84, 85-113 (cited in note 224).

226 Coleman, Risk and Wrongs at 354-60 (cited in note 222).

227 Perry, 77 Iowa L Rev at 496-513 (cited in note 218).

228 See Benson, 77 Iowa $L$ Rev at 543 (cited in note 223).

229 See Weinrib, The Idea of Private Law at 68-72 (cited in note 224).

230 See Coleman, Risks and Wrongs at 352-54 (cited in note 222); Weinrib, The Idea of Private Law at 208-14 (cited in note 224); Ronald Dworkin, Law's Empire 308-12 (Belknap 1986).
} 
justify compensation for constitutional torts, one would need both an appropriately tailored theory of corrective justice and a supplementary theory of the relative priorities of corrective and distributive justice. Until such a grand unified theory is presented, we are entitled to some degree of skepticism about the moral necessity of paying money to constitutional tort victims.

\section{Summary}

The relationship between this Part and the first two Parts is both complementary and thematic. It is complementary because conventional understandings of constitutional cost remedies take deterrence and compensation rationales to be mutually reinforcing. Courts and commentators who have assumed the deterrence benefits of making government pay the victims of takings and constitutional torts have been willing to live with casual and incomplete compensation-based justifications. This Part, by pointing out the limitations and lacunae of these justifications, has attempted to show that they cannot comfortably carry the entire weight of constitutional cost remedies. Deterrence must bear a large part of the justificatory burden. Consequently, the conceptual failure of the deterrence case for compensating the victims of takings and constitutional torts looms even larger.

Thematically, this Part joins the first two Parts in emphasizing some crucial differences between private firms and government that affect how we should think about the instrumental and noninstrumental consequences of constitutional cost remedies and about the market/politics distinction generally. Most prominent among these differences, government plays a distinctive role with respect to the distribution of wealth and entitlements in society. Because government has broadly legitimate authority both to allocate property rights and redistribute wealth (in most views), the injustice of takings is far more difficult to establish than the injustice of privately inflicted, nonconsensual redistributions. And while the injustice of constitutional torts may be analytic (despite the difficulty of identifying a "wrongdoer"), mandating cash transfers to the victims seems arbitrary against the background of the global distribution of wealth, and potentially perverse, given that government could redirect those transfers in pursuit of distributive justice. These points appear even more significant when we recognize that government is just a pass-through entity, and what is a stake is really a series of conflicting claims on social wealth by various groups of citizens. In this light, it is by no means obvious, for example, that takings condemnees or citizens who have been deprived of their free speech rights have a more compelling claim on social wealth than other, worse off groups of citizens, or even taxpayers generally. In short, whereas well functioning markets require relatively stable enti- 
tlements and relatively high levels of individual autonomy over the disposition of these entitlements, democratic politics often demands coerced redistribution. Using market criteria to evaluate the fairness or efficacy of democratic processes simply will not do.

\section{CONCLUSION}

Markets and politics are different institutions with different goals and mechanisms. Failing to appreciate these differences, conventional understandings of constitutional cost remedies have struggled to fit government into the market model. The result has been arbitrary and inconsistent predictions about government behavior. What is worse, the misguided assumption that putting a price tag on government activity will magically bring the market benefits of cost internalization to politics has led to uninformed over-investment in a system of constitutional remedies that may, for all we know, serve no useful purpose whatsoever. Appreciating the differences between politics and markets should lead us to ask what constitutional cost remedies actually accomplish.

As this Article has attempted to demonstrate, the instrumental and noninstrumental consequences of cost remedies appear quite different when placed against the background of politics instead of markets. Most fundamentally, the internalization of costs and benefits and the deterrent effects of constitutional cost remedies are not straightforward. To the contrary, predicting government behavior requires a deeper understanding of the causal relationship between social costs and benefits, financial inflows and outflows from the treasury, and the political incentives of government actors. Secondarily, the apparent fairness of requiring wrongdoers to compensate their victims becomes problematic in light of the special relationship between government and its citizens. As we have seen, government's role in redistributing wealth and entitlements may lead us to give priority to distributive justice over transactional justice and to reject claims of absolute ownership rights. Once we resist the temptation to reify government as a rational actor or moral agent with an identity independent of its votercitizens and a checking account to match, the consequences of compensation requirements look quite different from the perspectives of both deterrence and morality.

The picture that emerges, while lacking detail in many spots, should inspire skepticism about the desirability of mandatory compensation for takings and constitutional torts. Depending on the model of the political process employed as an exchange mechanism between financial and political costs, and on numerous contextual variables, the deterrence effects of compensation on government behavior seem as likely to be perverse as beneficial. The instrumental ef- 
fects of compensation on the behavior of private parties seem as likely to reduce allocational efficiency as to enhance it. Finally, the moral justifications for paying compensation offered by philosophers are universally problematic and contestable.

Skepticism is not the same as fatalism, however. Recognizing the precarious case for constitutional cost remedies may inspire research in two potentially profitable directions. First, more sophisticated models of government behavior would enable more confident predictions about the likely background levels of constitutional violations and takings and the incentive effects of compensation requirements. While there may be nothing useful to say in general about the effects of just compensation for takings on government behavior, it may be possible to generate quite useful rules of thumb for specific contexts. For example, we might be able to predict with greater confidence how the government of a small suburb will respond when it is required to pay just compensation every time it conditions the grant of a building permit on the confiscation of some land for bicycle pathways. ${ }^{231}$ Along the same lines, supplementing rational choice models of political and bureaucratic processes with empirically grounded studies offering thicker descriptions of the incentives and goals of legislatures and agencies of various kinds may generate more reliable, if less generalizable, results. The fact is, we currently know very little about how government behavior is affected when legislatures or agencies are forced to pay money to the victims of takings or constitutional torts, and highly abstract models may not be sufficient to carry us beyond broad agnosticism.

Second, the recognition that making government pay money is not an especially promising approach to constitutional remedies should lead us to think more seriously and systematically about alternatives. To mention the most obvious one, courts might rely more heavily on injunctions. ${ }^{22}$ Complex injunctions or structural reform might well be the best hope for preventing constitutional violations where a majority is willing to bear the costs of paying compensation

231 See Dolan v City of Tigard, 512 US 374 (1994).

232 While injunctions enforced by civil fines for contempt are in theory no different from cost remedies, unlike compensatory damages, the level of contempt sanctions can be adjusted upward until the political costs of noncompliance decisively outweigh the benefits. See, for example, Spallone v United States, 487 US 1251 (1988) (refusing to grant a stay of coercive contempt fines of up to $\$ 1$ million per day against the city of Yonkers until the city council enacted an ordinance to build public housing in order to remedy unconstitutional segregation). In addition, government officials who fail to comply with injunctions can be sent to prison as a civil or criminal sanction. Regarding sanctions for contempt, see Dan B. Dobbs, Law of Remedies: Damages-Equity-Restitution 130-62 (West $2 \mathrm{~d}$ ed 1993). These threats should ordinarily suffice to ensure compliance with injunctions, even with strong political incentives pushing in the other direction. 
or where a powerful interest group benefits from the unconstitutional activity. ${ }^{23}$ Structural reform brings enormous difficulties and costs, however, and may only be worthwhile in circumstances of severe and pervasive government wrongdoing. ${ }^{234}$

If merely adjusting the mix of existing remedies is not an adequate response to the failure of compensation to control government, then what are the alternatives? The dominant lesson taught by this Article's analysis of constitutional cost remedies is that government behavior responds to political, not market, incentives. Constitutional remedies will influence government behavior only insofar as they manage to shape these political incentives. Consider the exclusionary remedy for violations of the Fourth and Fifth Amendments. The remedy of exclusion was designed for the specific purpose of preventing constitutional violations by the police in the course of investigating crimes that had come to seem, at the time the exclusionary rule was constitutionally imposed on the states, impervious to deterrence through the conventional damages remedy. ${ }^{235}$ Indeed, as we have seen, damages do not reliably deter government because, although financial outflows may ultimately create political incentives, they do not constitute political incentives in their own right. ${ }^{226}$ In contrast, the exclusionary rule operates much more directly on the political incentives relevant to police officers. Both street-level cops and higher-level officers probably enjoy political rewards from arresting and convicting serious criminals far in excess of the political punishments stemming from the need to raise money to pay compensation. The exclusionary rule effectively eliminates these political rewards by derailing convictions-and in a highly visible, politically salient manner. The costs the exclusionary rule imposes on police for violating Fourth and Fifth Amendment rights, in other words, come in the same currency as the benefits the police capture from convicting criminals. ${ }^{237}$

233 See Dobbs, Law of Remedies at 177-79 (cited in note 232) (advocating the use of injunctions to control undesirable government conduct where damages remedies fail to deter).

234 See Schuck, Suing Government at 150-71 (cited in note 14) (surveying the difficulties of structural reform).

235 See Mapp v Ohio, 367 US 643, 652 (1961) ("[T]hat such other remedies have been worthless and futile is buttressed by the experience of other States.").

236 Commentators on the exclusionary rule who doubt the deterrence effects of damage suits do so for entirely unrelated reasons. See, for example, Pamela S. Karlan, Race, Rights, and Remedies in Criminal Adjudication, 96 Mich L Rev 2001, 2011-12 (1998) (encapsulating the conventional wisdom, which focuses on concerns such as the few claims brought by innocent victims of unconstitutional searches and the limited success of claims brought by guilty victims).

237 This is not to make any claims about the effectiveness of the exclusionary rule in controlling police misconduct or to overlook its other costs. For a general discussion of the empirical debate over the effects of the exclusionary rule, see Carol S. Steiker, Second Thoughts About First Principles, 107 Harv L Rev 820, 851-52 (1994) (noting the debate and citing sources). On the benefits and costs of the exclusionary rule, see William J.Stuntz, The Virtues and Vices of the Exclusionary Rule, 20 Harv J L \& Pub Pol 443 (1997). 
Perhaps the exclusionary rule is instructive. Could we not construct other constitutional remedies that would similarly influence government behavior by reliably modifying political incentives? For example, the takings clause might be enforced by selective nullification of takings that are not "for public use," interpreted to mean that the benefits of the takings are widely dispersed. As the analysis in Part II demonstrated, on an interest group model of the political process, increasing the size of the beneficiary coalition may tend to equalize political contests with the condemnee group (assuming no compensation payments). ${ }^{238}$ Part II also suggested that a "windfalls for wipeouts" system -in which compensation for takings victims is funded by taxes on takings beneficiaries - would effectively prevent inefficient takings in a majoritarian political process. ${ }^{239}$ Accordingly, courts might consider specifying the sources of funds used to pay just compensation as part of the "remedy" for takings. Courts could tax the very same individuals who benefit from a taking, or else, extending the idea to interest group politics, target taxation on a group with political power approximately equal to that of the beneficiary group. ${ }^{2+0}$ For instance, imagine the political consequences if, in response to an environmental taking of farmland, a court ordered just compensation financed through a gasoline tax. The resulting interest group match-up in the legislature, pitting drivers against environmentalists, might yield political incentives roughly correlative of the economic costs and benefits of the regulation.

Another promising approach to constitutional remedies might be to leverage the political effects of disseminating information about government action. Just as government increasingly uses mandatory disclosure as a tool for regulating private activity, courts might use disclosure requirements to regulate constitutional misconduct. ${ }^{2.1}$ For example, in situations where government engages in normatively undesirable behavior because of interest group pressure, and where a majority would oppose the behavior, disseminating information about the government action might provoke majoritarian punishment. Sup-

238 See note 90 and accompanying text. If compensation is paid, then enforcing the public use requirement might also tend to equalize political contests between the beneficiary group and taxpayers or the beneficiaries of substitute programs. Id. Note that on a majoritarian model, enforcing the public use requirement would only have salutary effects if compensation were paid. See note 63 and accompanying text.

239 See note 65 and accompanying text.

240 The idea of matching up beneficiaries of government spending programs and victims of the taxation necessary to fund those programs based on political organization is usually attributed to Gordon Tullock or James Buchanan. See Roin, 93 Nw U L Rev at 359 (cited in note 50).

241 Regarding informational regulation, see Wesley A. Magat and W. Kip Viscusi, Informational Approaches to Regulation (MIT 1992); Cass R. Sunstein, Informational Regulation and Informational Standing: Akins and Beyond, 147 U Pa L Rev 613 (1999). 
pose a homeowners association lobbies the city council to rezone a nearby lot for residential use only in order to prevent development of a landfill that would substantially benefit many city residents. Forcing the payment of just compensation to the owner of the landfill lot would simply buy off her political opposition to the inefficient zoning ordinance, making it all the more likely to succeed. On the other hand, publicizing the economic consequences of the ordinance would lower the information costs to the dispersed majority, potentially enabling them to organize politically to defeat the ordinance. The payment of compensation alone might sometimes have this salutary signaling effect-for example, by informing the public of higher levels of police brutality then they would otherwise have been aware. ${ }^{242}$ But judicial decisions, even those ordering the payment of money, are probably not the most effective form of publicity. Perhaps a remedial requirement of a public hearing or referendum before the zoning ordinance could go into effect, or the establishment of a citizen review board to investigate and publicize police brutality, would be better advertising. In other cases, where government misconduct is the result of bureaucratic drift, or the detours of the street-level officials from higher-level policy, publicizing the misconduct may reduce agency costs and assist bureaucratic sponsors or policymakers in bringing their agents into line. ${ }^{243}$

Finally, constitutional remedies might be targeted even more precisely at the immediate incentives of misbehaving officials. Suppose an elected police commissioner has ordered officers to use dangerous and unconstitutional chokeholds on suspects resisting arrests. As we have seen, under certain conditions majoritarian politics will reward this policy, even if the police are required to pay tax-financed compensation to each chokehold victim. ${ }^{244}$ The basic problem is that majorities will support "efficient breaches" of constitutional rules. But what if the court subtracted compensatory damage payments, or some multiple, from the campaign funding of the incumbent commissioner at the time of the next election? A police commissioner interested in

242 See Kevin Flynn, Record Payouts in Settlements Against the New York City Police Are Set for Year, NY Times A27 (Natl Ed) (Oct 1, 1999) (reporting that New York paid out $\$ 40$ million to police brutality claimants in the last fiscal year and noting the reaction of critics of the police department, who claim that this reflects unacceptably high levels of police misconduct). Of course this publicity will result in less police brutality only if the latent political opposition to brutality is sufficient. If most residents of New York actually benefit from this level of police aggression, then the publicity may not translate into political punishment.

243 This is the intuition behind "fire alarm" monitoring strategies. See McCubbins and Schwartz, 28 Am J Polit Sci 165 (cited in note 111).

244 See Part II.B.2. 
maximizing his prospects of reelection would at least then be confronted with conflicting incentives. Though a majority of voters might support his use of chokeholds, and though some might be sufficiently enthusiastic about the policy to increase their campaign donations, the commissioner would face the possibility that, if chokeholds continued, his available campaign contributions would be diminished on net. As compared to an injunction forbidding chokeholds altogether, ${ }^{245}$ we might even prefer a system that would allow the commissioner to balance the social benefits of resorting to chokeholds in particular cases, reflected in majoritarian political support, against the costs, reflected in reduced campaign funding. That, after all, is the role damages are meant to play-but cannot, unless money is somehow exchanged into votes. Extracting compensation in the form of campaign finance limitations might be one method of making that exchange.

Needless to say, each of these inventions is problematic in fairly obvious ways. Some may be Frankenstinian. The point of making these suggestions is not to defend practical proposals for reform, but to catalyze creative thought about ways of controlling government behavior that capitalize on the insight that government responds to political, not market, incentives. Constitutional cost remedies make government pay dollars for constitutionally problematic conduct, but government cares not about dollars, only about votes. The challenge is to find ways of closing this gap.

245 Under current doctrine, an injunction may not even be available in this situation. See City of Los Angeles $v$ Lyons, 461 US 95 (1983) (holding that plaintiff lacks standing to get injunction against unconstitutional police use of chokeholds unless he can show likelihood that he personally will be subjected to another chokehold in the future). 